Hydrol. Earth Syst. Sci., 17, 1661-1679, 2013

www.hydrol-earth-syst-sci.net/17/1661/2013/

doi:10.5194/hess-17-1661-2013

(C) Author(s) 2013. CC Attribution 3.0 License.

\title{
Importance of vegetation, topography and flow paths for water transit times of base flow in alpine headwater catchments
}

\author{
M. H. Mueller ${ }^{1}$, R. Weingartner ${ }^{2,3}$, and C. Alewell ${ }^{1}$ \\ ${ }^{1}$ Environmental Geosciences, University of Basel, Bernoullistrasse 30, 4056 Basel, Switzerland \\ ${ }^{2}$ Institute of Geography, University of Bern, Hallerstrasse 12, 3012 Bern, Switzerland \\ ${ }^{3}$ Oeschger Centre for Climate Change Research, University of Bern, Zähringerstrasse 25, 3012 Bern, Switzerland
}

Correspondence to: M. H. Mueller (matthiash.mueller@unibas.ch)

Received: 6 September 2012 - Published in Hydrol. Earth Syst. Sci. Discuss.: 27 September 2012

Revised: 29 March 2013 - Accepted: 4 April 2013 - Published: 30 April 2013

\begin{abstract}
The mean transit time (MTT) of water in a catchment gives information about storage, flow paths, sources of water and thus also about retention and release of solutes in a catchment. To our knowledge there are only a few catchment studies on the influence of vegetation cover changes on base flow MTTs. The main changes in vegetation cover in the Swiss Alps are massive shrub encroachment and forest expansion into formerly open habitats. Four small and relatively steep headwater catchments in the Swiss Alps (Ursern Valley) were investigated to relate different vegetation cover to water transit times.

Time series of water stable isotopes were used to calculate MTTs. The high temporal variation of the stable isotope signals in precipitation was strongly dampened in stream base flow samples. MTTs of the four catchments were 70 to 102 weeks. The strong dampening of the stable isotope input signal as well as stream water geochemistry points to deeper flow paths and mixing of waters of different ages at the catchments' outlets. MTTs were neither related to topographic indices nor vegetation cover. The major part of the quickly infiltrating precipitation likely percolates through fractured and partially karstified deeper rock zones, which increases the control of bedrock flow paths on MTT. Snow accumulation and the timing of its melt play an important role for stable isotope dynamics during spring and early summer.

We conclude that, in mountainous headwater catchments with relatively shallow soil layers, the hydrogeological and geochemical patterns (i.e. geochemistry, porosity and hydraulic conductivity of rocks) and snow dynamics influence storage, mixing and release of water in a stronger way than vegetation cover or topography do.
\end{abstract}

\section{Introduction}

The time of water traveling through a catchment gives information about storage, flow paths, sources of water and thus also about retention and release of solutes in a catchment (McDonnell et al., 2010; McGuire et al., 2005). The mean transit time (MTT) of water can be defined as the mean time that elapses from the input of water to a system until the output of that water (Eriksson, 1971; McDonnell et al., 2010). It can be calculated via stable isotopes of the water molecule (McGuire and McDonnell, 2006). The stable isotope signals in precipitation are influenced by air temperature, varying storm trajectories, precipitation amounts and relative air humidity (e.g. Ingraham, 1998). In regions with seasonally varying air temperatures, the stable isotope signature in precipitation also varies seasonally (Dansgaard, 1964). This variability can also be observed in stream flow samples but often is delayed and/or dampened, depending on the MTT and transport properties within the aquifer (McGuire and McDonnell, 2006).

Water storage and flow in the bedrock (e.g. Asano and Uchida, 2012; Gabrielli et al., 2012), landscape structure and topography (e.g. McGlynn et al., 2003; McGuire et al., 2005; Rodgers et al., 2005; Soulsby and Tetzlaff, 2008) play an important role as controlling factors on water transit times but their influence can vary in different environments. Gabrielli et al. (2012) found that tortuous flow paths through the deeper fractured bedrock of a headwater catchment in the H. J. Andrews Experimental Forest, USA, can lead to longer estimates of MTT of stream flow. In small mountainous catchments with shallow soil layers underlain 
by fractured granites in Japan, Asano and Uchida (2012) found that MTT of base flow was positively related to the contributing flow path depth. Their conclusion was based on dissolved silica concentrations in stream flow which could be used as a tracer to identify flow path depth. Soulsby and Tetzlaff (2008) analyzed a large catchment in Scotland and found that MTT correlates negatively with the percentage of soils which rapidly generate storm runoff and (counterintuitively) positively with mean catchment slope. The more freely draining soils, which can be found at steeper slopes in formerly glaciated landscapes, facilitate recharge to groundwater and subsequent mixing of pre-event and event waters, which therefore leads to longer MTT estimates. McGuire et al. (2005), on the other hand, found flow path gradient to the stream network to be negatively correlated to MTT of stream flow in small catchments of the H. J. A. Experimental Forest. In the studies of McGuire et al. (2005), Soulsby and Tetzlaff (2008) and Tetzlaff et al. (2011), the authors found that catchment area does not seem to influence MTT, whereas, e.g. Dewalle et al. (1997), found a positive correlation between the two parameters in three small forested catchments in the Appalachian Mountain, USA, which indicates that catchment surface characteristics partially control MTT.

To our knowledge there are several studies on the influence of land use/vegetation cover on the reaction of the catchments during storm events (e.g. Bariac et al., 1995; Buytaert et al., 2004; Monteith et al., 2006; Wenjie et al., 2011; Roa-Garcia and Weiler, 2010) but only a few catchment studies on the influence of vegetation cover on stream base flow MTTs (e.g. Roa-Garcia and Weiler, 2010). Wenjie et al. (2011) investigated the impact of land use on runoff generation processes in a small tropical seasonal rain forest catchment and a small artificial rubber plantation catchment. Soil compaction through land use changes resulted in higher amounts of infiltration-excess overland flow and subsequent higher fractions of event water in runoff. Monteith et al. (2006) studied hydrographs and groundwater transit times in a small harvested and a small undisturbed hardwood forest in Ontario, Canada. They found that mean groundwater transit time was not influenced by land use, at least not during a snowmelt period. Buytaert et al. (2004) investigated two small catchments in the Ecuadorian Andes under different land use (extensive grazing versus intensive grazing, cultivation and drainage). They found a substantially faster response of discharge to precipitation in the cultivated catchment compared to the extensively use catchment. Bariac et al. (1995) compared the runoff generation of small deforested and forested catchments in the north of French Guiana. Retention of precipitation was higher in the forested catchment, which the authors ascribe to soil porosity. Roa-Garcia and Weiler (2010) investigated three small catchments in the Columbian Andes with thick soil layers. Catchments differed in percentage of forest, grassland and wetlands. The authors found higher rates of stream discharge during precipitation events in the catchment with a higher percentage of grazed grassland, which is explained by compaction of soils. On the long time scale they found differences in the MTTs, which they ascribe to the difference in vegetation cover/land use, notably the occurrence of wetlands and forests which increased MTTs due to an increased water holding capacity (Roa-Garcia, 2009).

Darling and Bath (1988) measured more negative $\delta^{18} \mathrm{O}$ values in the percolate of a lysimeter compared to soil water samples of drill cores from the same depth. These two methods involve two distinct pools of soil water, i.e. fast and slowly moving water. Therefore, different flow patterns in the unsaturated zone can influence timing and stable isotope characteristics of soil water recharging to deeper bedrock zones. In a lysimeter study, Stumpp et al. (2009b) found that water flow was faster and MTT was shorter when the lysimeter surface was covered with maize compared to the periods when it was covered with canola or wheat. They concluded that soil hydraulic properties were changed by vegetation cover changes. Distinct root growth of different crops can partially explain their results. The influence of roots on water infiltration into and flow within the soil was suggested by Beven and Germann (1982). Several studies confirmed the importance of root induced preferential flow (Bundt et al., 2001) and especially the influence of different land use (i.e. vegetation types) on preferential flow (Bachmair et al., 2009; Jinhua et al., 2010).

The main changes in vegetation cover in the Swiss Alps are massive shrub (mainly Alnus viridis and also Sorbus aucuparia; see also Sect. 2.1) encroachment and forest expansion into formerly open habitats (Tasser et al., 2005; Wettstein, 1999). In the Ursern Valley the shrub cover increased by $32 \%$ between 1965 and 1994 (Wettstein, 1999) and again by $24 \%$ between 1994 to 2004 (van den Bergh et al., unpublished data). Since shrub encroachment can increase saturated hydraulic conductivity of soils (Alaoui et al., 2013), we hypothesize that higher infiltration rates of water into the unsaturated zone and subsequent recharge to groundwater in the bedrock will result in longer MTTs.

In four alpine micro catchments we modeled the MTT under base flow conditions using stable water isotopes. Our sampling approach enabled us to estimate the influence of vegetation cover as well as topography on MTT under the same geological and climatological conditions. Furthermore, we evaluate additional geochemical data, which also allows us to estimate the contribution of groundwater to base flow runoff and its influence on MTT.

\section{Material and methods}

\subsection{Study site}

The Ursern Valley (Fig. 1) has a U-shaped profile and is characterized by rugged terrain. Elevation ranges from 1400 to 


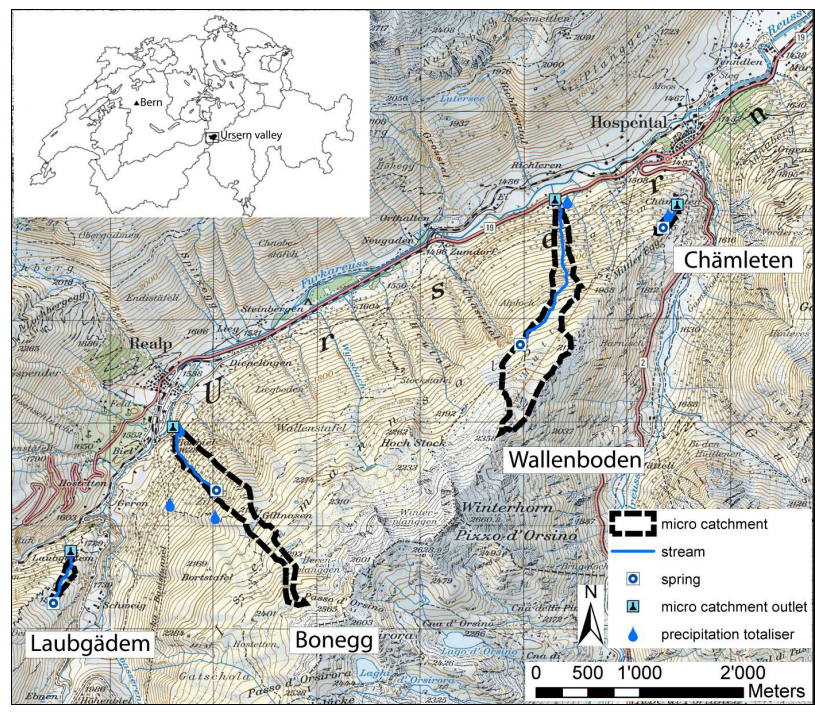

Fig. 1. Location of the micro catchments in the Ursern Valley. Micro catchment limits from van den Bergh et al. (2011) and Fercher (2013), modified. Geodata reproduced by permission of swisstopo (BA12066).

$3200 \mathrm{~m}$ a.s.l. The whole catchment covers an area of $191 \mathrm{~km}^{2}$ and is drained to the north-east by the Reuss River. The southern mountain ridge is built by the gneiss massif of the Gotthard system whereas the northern mountains are part of the granite massif and the pre-existing basement of the Aar system (Labhart, 1977). The two massifs are separated by intermediate vertically dipping layers along a geological fault line which corresponds to the valley axis. These layers consist of Permocarbonic and Mesozoic sediments and they comprise sandstones, rauhwackes, dolomites, dark claymarls and limestones. Throughout the formation of the Alps the material was metamorphosed to schist (Ambuehl, 1929). Due to erosion of these soft layers a depression developed (Kägi, 1973). The soluble limestones and also gypsum rich rocks, which are prone to karst formation, underlie the outcropping rocks or are incorporated as lenses in the granites and gneisses (Ambuehl, 1929; Buxtorf, 1912; Labhart, 1977; Winterhalter, 1930). The most abundant outcropping bedrock material is a white mica-rich gneiss. This was confirmed by the detection of phyllosilicates (muscovite/illite) in the soil by X-ray diffraction (Schaub et al., 2009).

Podsols, Podzocambisols and Cambisols are the dominant soil types in the valley (Meusburger and Alewell, 2008). At higher elevations and on steep valley slopes, Leptosols are common. At the valley bottom and lower slopes, predominantly clayey gleyic Cambisols, Histosols, Fluvisols and Gleysols developed.

The valley is characterized by a high mountain climate with a mean air temperature of $3.1^{\circ} \mathrm{C}$ (1901 to 1961). Mean annual rainfall at the climate station in Andermatt (1442 m a.s.l.) of MeteoSwiss is about $1400 \mathrm{~mm}$. The valley is snow covered for 5 to 6 months (from November to April) with maximum snow height in March (Angehrn, 1996). Runoff is usually dominated by snowmelt in May and June.

Vegetation shows strong anthropogenic influences due to pasturing for centuries (Kägi, 1973). An invasion of shrubs mainly by Alnus viridis, Calluna vulgaris, Salix appendiculata, Sorbus aucuparia and Rhododendron ferrugineum was identified, particularly on the north-facing slopes (Kägi, 1973; Küttel, 1990; Wettstein, 1999). The southfacing slopes are dominated by dwarf-shrub communities of Rhododendron ferrugineum and Juniperus sibirica (Kägi, 1973; Küttel, 1990) and diverse herbs and grass species. Wettstein (1999) estimated that approximately one third of shrubs (mainly consisting of Alnus viridis and Sorbus aucuparia) have invaded since 1965 . For more detailed information about the Ursern Valley, the reader is referred to Meusburger and Alewell (2008).

Four micro catchments located on north-east and northwest facing slopes in the Ursern Valley (Table 1 and Fig. 1) were chosen with regard to their differing percentage of shrub cover. The steep micro catchments are smaller than $1 \mathrm{~km}^{2}$ and shrub vegetation covers a range from 13.8 to $82.2 \%$. The Chämleten micro catchment also includes several wetland sites which presumably play an important role for the hydrology in this micro catchment. From field observations we can assume that mean discharge during the snow covered period is at the lower end of the discharge range given in Table 1. In all micro catchments small springs could be indentified as the starting point of the streams permanently discharging water (also observed in winter months) (Fig. 1).

\subsection{Sampling and analysis}

\subsubsection{Precipitation, discharge and stable water isotopes}

Precipitation was continuously measured with a Davis Vantage pro2 weather station at the MeteoSwiss station Andermatt by the Swiss Federal Office of Meteorology and Climatology (MeteoSwiss, 2012). Discharge was measured with pressure transducers (PDCR1830, Campbell Scientific) and a radar sensor (Vegapuls61, VEGA). Discharge data availability was restricted to summer months because streams and installed weirs were completely snow covered and/or frozen during winter. We sampled precipitation and stream base flow biweekly for stable isotope analysis from March 2010 to May 2012. Precipitation was sampled near the catchment outlets with a $200 \mathrm{~cm}^{2}$ totalizer and a buried and covered $5 \mathrm{~L}$ bottle to protect the water from evaporation. Precipitation amount was determined and a subsample was transferred in a $250 \mathrm{~mL}$ poly ethylene (PE) bottle. In summer 2010 we installed three precipitation samplers at an elevation gradient ranging from 1600 to $2100 \mathrm{~m}$ a.s.l. in the Bonegg micro catchment to determine a possible elevation gradient in stable isotope values of precipitation. 
Table 1. Characteristics of micro catchments (vegetation data from van den Bergh et al., 2011, and Fercher, 2013 (modified); discharge data from Lagger, 2012, and Schmidt, 2012).

\begin{tabular}{|c|c|c|c|c|}
\hline & Chämleten & Wallenboden & Bonegg & Laubgädem \\
\hline projected area $\left(\mathrm{km}^{2}\right)$ & 0.01981 & 0.56431 & 0.34302 & 0.02981 \\
\hline $\begin{array}{l}\text { shrub cover (mainly Alnus viridis } \\
\text { and Sorbus aucuparia) }(\%)\end{array}$ & 82.2 & 13.8 & 38.5 & 14.5 \\
\hline vegetation cover $(\%)$ & 100.0 & 78.9 & 95.9 & 100.0 \\
\hline elevation range ( $m$ a.s.l.) & $1669-1810$ & $1501-2354$ & $1551-2492$ & $1721-1915$ \\
\hline mean elevation (m a.s.1.) & 1740 & 2082 & 2026 & 1836 \\
\hline slope range $\left({ }^{\circ}\right)$ & $4.0-55.7$ & $0.6-60.5$ & $0.5-73.1$ & $0.3-49.3$ \\
\hline mean catchment slope $\left(^{\circ}\right)$ & 24 & 20 & 28 & 20 \\
\hline aspect & NE & NNW & NW & NE \\
\hline range of discharge $\left(\mathrm{Ls}^{-1}\right)$ & $0.09-36.02$ & $0.46-44.03$ & $2.00-93.54$ & $0.10-14.61$ \\
\hline $\begin{array}{l}\text { mean discharge }\left(\mathrm{Ls}^{-1}\right) \\
(\text { summer } 2010 \text { and } 2011)\end{array}$ & 1.08 & 2.42 & 6.3 & 2.91 \\
\hline
\end{tabular}

Stream water was also sampled by hand with $250 \mathrm{~mL}$ PE bottles which were filled completely. Samples were taken at base flow conditions defined as the "baseline" of the hydrograph when discharge was not increased by the influence of precipitation events. When a storm event coincided with a planned sampling day, we adapted our strategy and sampled one day in advance or after the originally fixed day. This is justified since storm flow peaks decreased back to pre-event conditions very fast within a few hours after the precipitation event, which was confirmed by discharge measurements. During five weeks from April to May 2012, we also sampled stream water in the Wallenboden and Bonegg micro catchments on a daily basis (except during high avalanche risk) to capture snowmelt runoff. Snow was sampled during the winter period as bulk samples with a plastic tube of $2 \mathrm{~m}$ length and a diameter of $3.5 \mathrm{~cm}$. Each complete bulk snow sample was transferred into a $2 \mathrm{~L} \mathrm{PE}$ bottle. After melting of the snow we took a subsample for stable isotope analysis. Snow water equivalent was calculated from the known snow volume and snow density. Monthly samples were taken near the micro catchments' outlets. In March 2010, 2011 and 2012, shortly before the onset of snowmelt, we sampled snow spatially distributed over several kilometers along the valley slopes from 1500 to $2700 \mathrm{~m}$ a.s.1., depending on weather conditions and avalanche situation. A few snow samples on shadowed spots were also taken at the end of April 2011 when substantial snowmelt in most parts of the catchments had already happened. The bulk snow samples were used for MTT modeling (see below). For a discussion of fractionation of stable isotopes in snow samples, see also Sect. 3.2.2.

Stable isotopes were measured with a Thermo Finnigan GasBench II connected to a DELTAplus XP continuous flow mass spectrometer (CF-IRMS, DELTAplus XP, Thermo, Bremen, Germany) and a liquid water isotope analyzer (Los Gatos Research, Inc. (LGR), Mountain View, USA). Results are reported as $\delta^{18} \mathrm{O}$ or $\delta^{2} \mathrm{H}$ in $\%$ vs. the VSMOW standard. Precisions are $0.05 \%$ for $\delta^{18} \mathrm{O}$ and $1 \%$ for $\delta^{2} \mathrm{H}$ with the IRMS and $0.1 \%$ for $\delta^{18} \mathrm{O}$ and $0.3 \%$ for $\delta^{2} \mathrm{H}$ with the LGR instrument, respectively. Samples were calibrated to known standards (V-SMOW, SLAP and GISP).

\subsubsection{Additional geochemical parameters}

In addition to the use of stable isotopes as a time orientated tracer, we also measured various geochemical parameters which served as geogenic tracers. Total dissolved alkali and earth alkali metals ( $\mathrm{Ca}, \mathrm{Mg}, \mathrm{K}, \mathrm{Na}$ ) and silicon ( $\mathrm{Si}$ ) were measured by Inductively Coupled Plasma Optical Emission Spectrometry (ICP-OES, Spectro Genesis, Spectro Analytical Instruments, Germany). These elements can be found in aqueous solutions due to weathering of minerals and can be an indicator of the type of rocks which are weathered (Stumm and Morgan, 1996). Major anions were measured by ion chromatography (761 Compact IC, Metrohm, Switzerland). Sulfate in stream water can be an indicator for weathering of gypsum bearing rocks (Stumm and Morgan, 1996). PH was measured continuously during the summer periods with a CS525 ISFET pH Probe (Campbell Scientific, UK) and on a monthly basis during winter with a portable $\mathrm{pH} 340 \mathrm{i}$ probe (WTW, Weilheim, Germany).

All stream water samples for geochemical parameter determination were taken by hand in the field, filtered with $0.45 \mu \mathrm{m}$ filters (Rotilabo-filter, PVDF, Roth, Switzerland), cooled during transport to the laboratory and kept frozen at $-20^{\circ} \mathrm{C}$ until analysis.

\subsection{Mean water transit time modeling}

We determined MTTs from biweekly stable isotope data of precipitation and stream base flow $\left(\delta^{18} \mathrm{O}\right.$ of $\left.\mathrm{H}_{2} \mathrm{O}\right)$. The stable isotope data of precipitation were corrected for the elevation gradient (see results) using the difference between elevation of catchment base and mean catchment elevation. Stable isotope values of monthly winter samples were stepwise interpolated. We used the modeling procedure suggested, e.g. by Maloszewski and Zuber $(1982,2002)$ and their provided 
software FlowPC. From a known isotope input signal (precipitation samples) and the measured output signal in the four streams (base flow samples), MTTs can be modeled by solving a convolution integral which relates input and output stable isotope signals with water transit times:

$\delta^{18} \mathrm{O}_{\text {out }}(t)=\int_{0}^{\infty} \delta^{18} \mathrm{O}_{\text {in }}(t-\tau) g(\tau) \mathrm{d} \tau$

where $\delta^{18} \mathrm{O}_{\text {out }}$ is the output signal, $\delta^{18} \mathrm{O}_{\text {in }}$ is the input function, $g(\tau)$ the system response function and $\tau$ is the transit time.

The use of a MTT, which we calculate via this approach, is subject to some assumptions which are not always met in nature. For example, steady state of flow, linear tracer input-output relations and an equal distribution of precipitation over the entire catchment are assumed (Turner and Barnes, 1998). Recent studies have shown that transit time distributions are not time-invariant, which reflects the variability of climate, precipitation and hydrological conditions (e.g. Botter et al., 2011; Heidbuechel et al., 2012; McGuire et al., 2007). On the other hand, the hydrological response of a catchment is also subject to quasi-stationary characteristics as, for example, topography and structure of the subsurface (Hrachowitz et al., 2010). Despite the above mentioned assumptions, the MTTs are useful to inter-compare the behavior of catchments (McDonnell et al., 2010; Soulsby et al., 2010) and our aim is to compare four small catchments under the same boundary conditions (climate, geology, geomorphology and considered time span).

The use of a lumped parameter model offers the advantage that it only requires few parameters and is useful in catchments where information on hydraulic properties of underlying material is scarce (Maloszewski and Zuber, 1982, 2002). Furthermore, the provided software does not require extensive hydrological or meteorological data. Especially discharge data were not available for the winter periods in our micro catchments. Therefore, more complex models, which take output flow into account (e.g. Rodhe et al., 1996), could not be applied in our study.

The system response function $g(\tau)$ describes the transit time distribution in the aquifer and hence implicitly includes hydraulic properties of the aquifer. We tested all the different system response functions $g(\tau)$ implemented in the software: the exponential, the exponential-piston-flow, the dispersion, the piston-flow and the linear model. The exponential model, which can be regarded as a special case of the gamma distribution model (e.g. Amin and Campana, 1996; Kirchner et al., 2000), is mathematically equivalent to a well-mixed reservoir. However, mixing only occurs at the system outlet (Maloszewski and Zuber, 1982, 2002). There is no exchange of tracer along the flow lines in the aquifer. The dispersion model, on the other hand, allows mixing of tracer within the aquifer itself. Using the exponential model would imply that there exists water with very short and water with very long transit times which only mix at the outlet. More detailed information about the flow models can be found in Maloszewski and Zuber (1982).

The stable isotope input function for the MTT modeling has to be weighted with the precipitation amount and recharge factor $\alpha$ (also called infiltration coefficient in the cited literature) (Maloszewski and Zuber, 1982, 2002; Grabczak et al., 1984):

$$
\delta^{18} \mathrm{O}_{\text {in }}\left(t_{i}\right)=\frac{N \cdot \alpha_{i} \cdot P_{i}}{\sum_{i=1}^{N} \alpha_{i} \cdot P_{i}} \cdot\left(\delta^{18} \mathrm{O}_{i}-\delta G\right)+\delta G
$$

$N$ is the number of single sampling events, $P_{i}$ and $\delta^{18} \mathrm{O}$ are precipitation rates and its isotope values and $\delta G$ is the mean value of $\delta^{18} \mathrm{O}$ of the local groundwater originating from recent precipitation. Recharge factors are often difficult to estimate and are often even unknown (Grabczak et al., 1984; Maloszewski and Zuber, 2002). They can, for example, be estimated as a ratio of summer recharge to winter recharge from stable isotope data (Grabczak et al., 1984) (Eq. 3) or calculated from the water balance (Stumpp et al., 2009a) (Eq. 4).

$$
\begin{aligned}
\alpha & =\frac{\left(\overline{\delta P_{\mathrm{W}}}-\delta G\right) \sum_{i}\left(P_{i}\right)_{\mathrm{W}}}{\left(\delta G-\overline{\delta P_{\mathrm{S}}}\right) \sum_{i}\left(P_{i}\right)_{\mathrm{S}}} \\
\alpha_{i} & =\frac{P_{i}-\mathrm{ET}_{\mathrm{a}, i}}{P_{i}}
\end{aligned}
$$

$\overline{\delta P_{\mathrm{W}}}$ and $\overline{\delta P_{\mathrm{S}}}$ are the long-term weighted mean values of $\delta^{18} \mathrm{O}$ for the winter and summer precipitation $(P)$, respectively and $\mathrm{ET}_{\mathrm{a}, i}$ is the actual evapotranspiration.

Since in our case the volume weighted mean stable isotope signal in precipitation for the whole observation period equals the mean of base flow stream samples, we conclude that summer and winter precipitation equally contribute to the stable isotope signal in stream base flow. Therefore, the recharge factor calculated according to Grabczak et al. (1984) as a ratio of summer recharge to winter recharge is equal to 1 . This would not represent the real situation since snow accumulates from November to March and recharge during winter would only occur when short warm periods induce snowmelt. The isotope signal from this winter precipitation will substantially recharge and contribute to the base flow signal only during the spring snowmelt and early summer. We therefore made a simplification and estimated the recharge factors for the snow accumulation period to be 0.01 . This low value is justified because only small amounts of meltwater were measured in several snow lysimeter studies during accumulation period (e.g. Gurtz et al., 2003).

Snowmelt was introduced into the model via the weighting procedure by recharge factors (set to 1 ) and precipitation amounts which accumulated during the winter season. 
Table 2. Description of the different model input parameter sets.

\begin{tabular}{|c|c|}
\hline & Description of input parameters \\
\hline set A & $\begin{array}{l}\text { raw } \delta^{18} \mathrm{O} \text { values of precipitation, not weighted by precipitation volume or } \\
\text { recharge, i.e. all precipitation enters the system and no snow accumulation occurs }\end{array}$ \\
\hline set B & $\begin{array}{l}\delta^{18} \mathrm{O} \text { values of precipitation weighted by precipitation volume; recharge factor } \alpha= \\
1 \text {, i.e. all precipitation enters the system, no snow accumulation occurs }\end{array}$ \\
\hline set $\mathrm{C}$ & $\begin{array}{l}\delta^{18} \mathrm{O} \text { values of precipitation weighted by precipitation volume and recharge into } \\
\text { the system as described in Sect. } 2.3 \text { : recharge factors } \alpha_{\text {winter }}=0.01, \alpha_{\text {snow melt }}= \\
\alpha_{\text {summer }}=1 \text {; snow accumulates during winter and is released during snowmelt; } \\
\text { precipitation volume corrected for evapotranspiration and direct runoff; } \delta^{18} \mathrm{O} \\
\text { values corrected for mean catchment elevation }\end{array}$ \\
\hline set D & $\begin{array}{l}\text { similar to set } \mathrm{C} \text {, but snowmelt water of the first input interval is reduced by } 2 \% \text { o } \\
\text { (estimated value according to Taylor et al., 2001), which increases influence of } \\
\text { the snowmelt on stream water stable isotope signals }\end{array}$ \\
\hline set E & $\begin{array}{l}\text { similar to set } \mathrm{C} \text {, but recharge factor } \alpha \text { during winter is set to } 0.1 \text {, which increases } \\
\text { influence of inputs on stream water stable isotope signals during the winter season }\end{array}$ \\
\hline
\end{tabular}

From field observation and data from MeteoSwiss (2012), we know that snowmelt occurs from the end of March until the beginning of May. Accumulated snow during winter was therefore released during snowmelt within six weeks in our model. At the lower part of our micro catchments, snow had melted at the beginning of April whereas snow in the upper regions lasted a few weeks longer. The recharge factor during the summer period was calculated similar to Stumpp et al. (2009a) by correcting measured precipitation for evapotranspiration and direct flow (which was calculated from the hydrographs according to Wittenberg, 1999, by the Institute of Geography, Section Hydrology, University of Bern).

To account for uncertainty in model input parameters including $\delta^{18} \mathrm{O}$ values of precipitation, precipitation volume and recharge factor $\alpha$-we conducted an uncertainty analysis with different parameter sets A to E (Table 2). The simplest parameter set $\mathrm{A}$ includes raw $\delta^{18} \mathrm{O}$ values of precipitation and the more complex sets $\mathrm{C}$ to $\mathrm{E}$ are generated as described above, considering snow dynamics. With these different sets we can estimate a range of most plausible MTTs.

The stable isotope values of stream water are calculated via Eq. (1) by choosing a system response function and a MTT. Calibration of the model is carried out by a trial-anderror procedure comparing the modeled stable isotope values of stream water with the measured values via the $\sigma$ value, as defined by Maloszewski and Zuber (2002):

$\sigma=\frac{\sqrt{\sum_{i=1}^{n}\left(c_{\mathrm{m} i}-c_{i}\right)^{2}}}{n}$

$-c_{\mathrm{m} i}=$ measured stable isotope value at time $i$,

$-c_{i}=$ modeled stable isotope value at time $i$,

$-n=$ number of measurements.
This value can be used to compare model results for different parameter sets. The trial-and-error procedure aims to minimize the $\sigma$ values. We also report the model efficiency $(E)$ according to Nash and Sutcliffe (1970) for the best fits according to the values of $\sigma$. Further description of the uncertainty and sensitivity analysis can be found in Sect. 3.2.1.

\subsection{Vegetation cover, topographic and hydrogeological analysis}

Vegetation cover and catchment topography were assessed by van den Bergh et al. (2011) and by Fercher (2013) by a combination of satellite images and field observation, and modified after additional field observations. Vegetated and bare lands were classified using maximum likelihood classification and a number of training samples on a composite spot image from the summer of 2004/2005. A map of vegetated and non-vegetated land was thus created. The remaining vegetation cover classes were manually drawn from Swissimage orthophotos (van den Bergh et al., 2011). The uncertainty of catchment area and shrub cover is about 5 to $10 \%$. Further topographic and hydrogeological analysis was performed with a digital elevation model with a cell size of $2 \times 2 \mathrm{~m}$ below $2000 \mathrm{~m}$ a.s.l. and $25 \times 25 \mathrm{~m}$ above $2000 \mathrm{~m}$ a.s. 1 . We used the geographic information system (GIS) software ArcGIS (ESRI) version 10 and its included hydrology tools.

To relate MTT to topographic features of the micro catchments, we determined ranges and means of the following parameters: slope, elevation, flow length, topographic wetness index, stream length and drainage density. Flow length was calculated as the downslope distance from each cell to the catchment outlet along the flow path. Topographic wetness index was computed as

$\mathrm{TWI}=\ln \frac{A}{\tan \beta}$, 
where $A$ is the upslope area per unit contour length and $\beta$ is the local slope (Beven and Kirkby, 1979). For stream length we determined two values. We defined length of base flow stream as the length of the perennial streams. Length of event flow streams additionally includes ephemeral streams, which are presumably activated during rainfall events. Drainage densities were computed for both length parameters by dividing stream length by micro catchment area.

For further hydrogeological analysis we calculated the mean mobile catchment storage as

$V_{\mathrm{H}_{2} \mathrm{O}}=\frac{Q_{\text {mean }}}{\text { MTT }}$,

where $Q_{\text {mean }}$ is the mean discharge. We then used the mean mobile catchment storage and an estimated volume of rocks ( $\left.V_{\text {rocks }}\right)$ to calculate a mean porosity $n_{\text {mean }}$ for the whole catchment as

$n_{\text {mean }}=\frac{V_{\mathrm{H}_{2} \mathrm{O}}}{V_{\text {rocks }}}$.

The volume of rocks was determined with the ArcHydro tool "terrain morphology" (version 2.0 for ArcGIS 10).

From the topographic data we also estimated the flow path length $x$ to calculate the tracer velocity $(v)$ as

$v=\frac{x}{\mathrm{MTT}} \cdot n_{\text {mean }}$.

These data were subsequently used to calculate the hydraulic conductivity $(K)$ with Darcy's law:

$K=\frac{v}{\frac{\Delta h}{L}}$,

where $\frac{\Delta h}{L}$ is the hydraulic gradient (e.g. Zuber, 1986).

\section{Results and discussion}

\subsection{Stable water isotopes in precipitation and runoff}

Decrease of $\delta^{18} \mathrm{O}$ in liquid precipitation along an elevation gradient was $0.15 \%$ o per $100 \mathrm{~m}$ elevation increase. This is only slightly lower than the measured decrease for locations on the Swiss plateau and in the western Alps by Siegenthaler and Oeschger (1980) $(0.26 \%$ per $100 \mathrm{~m})$ and in general in good agreement with other values from the Austrian Alps (Ambach et al., 1968, 0.2\% per $100 \mathrm{~m}$ ). We could not detect a clear elevation gradient in $\delta^{18} \mathrm{O}$ for bulk snow samples with elevation during winter (Fig. 2). At our sites the elevation gradient of stable isotopes is most probably caused by Rayleigh processes during the orographic uplift of air masses during storm events. Also, Rayleigh fractionation during precipitation coming from clouds at the same altitude can lead to the elevation gradient (Gat, 1996). The direction of the elevation gradient then depends on the storm trajectories. In winter the elevation gradient was not clearly pronounced and it was even reversed for some of our samples near Wallenboden and Chämleten in March 2010. These slopes can be on the lee side of a storm during winter, which can lead to the reversed elevation gradient of stable isotopes (Friedman and Smith, 1970; Moran et al., 2007).

Stream water and especially precipitation samples cover a wide range of $\delta^{18} \mathrm{O}$ and $\delta^{2} \mathrm{H}$ values (Fig. 3). The local meteoric water line (LMWL) matches the global meteoric water line (GMWL) (Craig, 1961). The GMWL gives the relation between $\delta^{2} \mathrm{H}$ and $\delta^{18} \mathrm{O}$ in meteoric waters (including, e.g. precipitation, groundwater and water from streams or lakes) on a global scale which have not undergone excessive evaporation. Our stream water samples are between the minimum and maximum values of our measured precipitation samples (Fig. 3). Therefore, stream water most likely represents a mixture of local precipitation from different dates. Since stream water samples plot close to the LMWL, we can presume that evaporation or other processes which would move the stream samples away from the LWML are negligible (Clark and Fritz, 1997).

As expected, the stable isotope signal $\left(\delta^{18} \mathrm{O}\right)$ of precipitation strongly varied between seasons and ranged from $-2.5 \%$ o during summer storms to $-25 \%$ (V-SMOW) for fresh snow samples (Figs. 3 and 4). The $\delta^{18} \mathrm{O}$ values of the four micro catchments followed a rather parallel pattern even though they are distributed along the valley within a distance of about $8 \mathrm{~km}$ (Fig. 1). The $\delta^{18} \mathrm{O}$ values of precipitation samples (both summer precipitation as well as bulk snow samples in winter) slightly decrease from the Chämleten to the Laubgädem micro catchment. This east-west trend could be attributed to an air temperature trend with decreasing temperature from east to west along the valley (note that the difference of mean $\delta^{18} \mathrm{O}$ values of precipitation is statistically not significant) or to the rainout effect for storms traveling from east to west. The east-west trend of $\delta^{18} \mathrm{O}$ is more pronounced and consistent throughout the year in the base flow samples (Fig. 5 and Table 3). The difference of mean base flow samples between the Chämleten and Laubgädem micro catchments is about $1 \%$ o $(p<0.01)$. In addition to the slight eastwest trend of $\delta^{18} \mathrm{O}$ of precipitation, this could also point to a stronger influence of isotopically lighter winter precipitation from higher elevations at $2760 \mathrm{~m}$ a.s.l. above the Laubgädem micro catchment surface area.

The parallel pattern in the precipitation samples was only interrupted at the beginning of the winter in 2010 when first freshly fallen snow of this winter period was sampled. The high variation could be due to non-equilibrium processes during the formation of solid precipitation (Gat, 1996) combined with spatially highly variable meteorological conditions in this complex terrain.

The strong seasonal variability of $\delta^{18} \mathrm{O}$ values in precipitation could hardly be detected in our biweekly base flow samples due to a strong dampening of isotope input signals. The isotope signal of precipitation was, however, reflected 

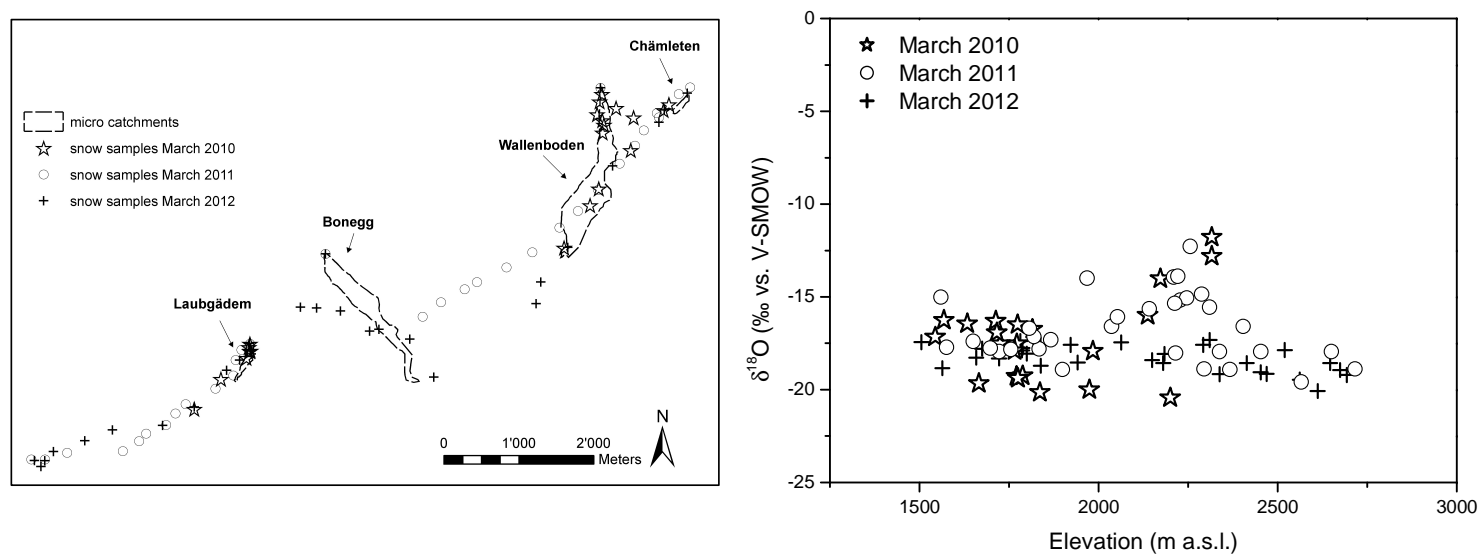

Fig. 2. Location of snow sampling at the end of the winter (left) and stable isotopes values of snow (right).

Table 3. Mean water transit times (MTT) and hydrogeological parameters of the micro catchments (means \pm standard deviations calculated for parameter sets $\mathrm{C}$ to $\mathrm{E})$.

\begin{tabular}{lllll}
\hline & Chämleten & Wallenboden & Bonegg & Laubgädem \\
\hline mean $\delta^{18} \mathrm{O}_{\text {base flow }}(\%$ o & -12.90 & -13.09 & -13.64 & -13.83 \\
MTT (weeks) & $76 \pm 7$ & $75 \pm 5$ & $70 \pm 6$ & $102 \pm 5$ \\
$V_{\mathrm{H}_{2} \mathrm{O}}\left(\mathrm{m}^{3}\right)$ & $5 \times 10^{4} \pm 5 \times 10^{3}$ & $1 \times 10^{5} \pm 7 \times 10^{3}$ & $3 \times 10^{5} \pm 2 \times 10^{4}$ & $2 \times 10^{5} \pm 9 \times 10^{3}$ \\
$V_{\text {rocks }}\left(\mathrm{m}^{3}\right)$ & $1 \times 10^{6}$ & $2 \times 10^{8}$ & $2 \times 10^{8}$ & $2 \times 10^{6}$ \\
porosity $n_{\text {mean }}(-)$ & $4 \times 10^{-2} \pm 3 \times 10^{-3}$ & $7 \times 10^{-4} \pm 5 \times 10^{-5}$ & $2 \times 10^{-3} \pm 1 \times 10^{-4}$ & $8 \times 10^{-2} \pm 4 \times 10^{-3}$ \\
$K\left(\mathrm{~m} \mathrm{~s}^{-1}\right)$ & $3 \times 10^{-7}$ & $8 \times 10^{-8}$ & $1 \times 10^{-7}$ & $1 \times 10^{-6}$ \\
\hline
\end{tabular}

$V_{\mathrm{H}_{2} \mathrm{O}}=$ mobile catchment storage; $V_{\text {rocks }}=$ volume of rocks; $K=$ hydraulic conductivity.

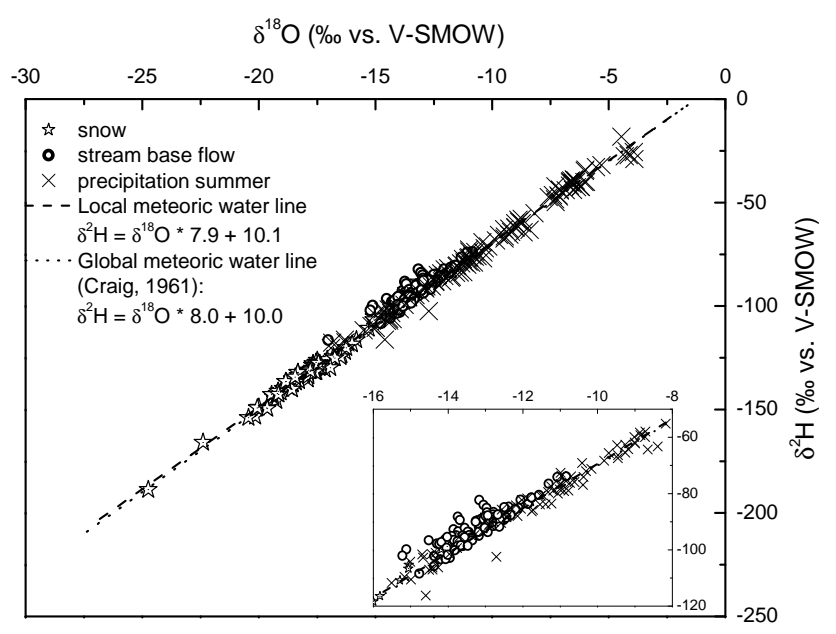

Fig. 3. $\delta^{18} \mathrm{O}$ vs. $\delta^{2} \mathrm{H}\left(\right.$ of $\left.\mathrm{H}_{2} \mathrm{O}\right)$ in precipitation and stream water base flow.

in the stream water during snowmelt (Fig. 4). The strong attenuation of the input signal implies that only small fractions of the precipitation leave the basin via surface runoff in short time periods (Herrmann and Stichler, 1980). Precipitation from different events and seasons can therefore mix when this water reaches the catchments' outlets.
Variability of $\delta^{18} \mathrm{O}$ of stream water was most pronounced in the Chämleten micro catchment with $\delta^{18} \mathrm{O}$ values of $-15 \%$ in winter and up to $-11.5 \%$ in summer. $\delta^{18} \mathrm{O}$ of stream water varied very little in the other micro catchments. Especially the Laubgädem micro catchment exhibits an extremely dampened isotope signal, with the exception of 29 April 2010 when discharge was highly increased due to high snowmelt inputs. These very sharp snowmelt peaks were not detected for our biweekly samples in spring 2011 and 2012. Snowmelt in 2010 occurred later than in 2011 but in a shorter time period. Therefore, the isotope signal of the snow was transferred to the stream quicker and produced a sharp peak in 2010. In 2011 there was only half of the snow amount (snow depth was around $50 \mathrm{~cm}$ at the onset of snowmelt) and snowmelt took place earlier. We therefore might have missed the sharp peak in 2011. From the more detailed sampling during the snowmelt in the Wallenboden and Bonegg micro catchments in 2012 (Fig. 4) we know that these sharp peaks appear within a few days only, which are easily missed by the 14 day sampling interval (Bucher, 2013). On 28 April 2012 the stream water in the Bonegg micro catchment had a $\delta^{18} \mathrm{O}$ value of $-15.8 \%$, which was not captured with the 14 day sampling approach (data not included in MTT model evaluation but shown in Fig. 4). 

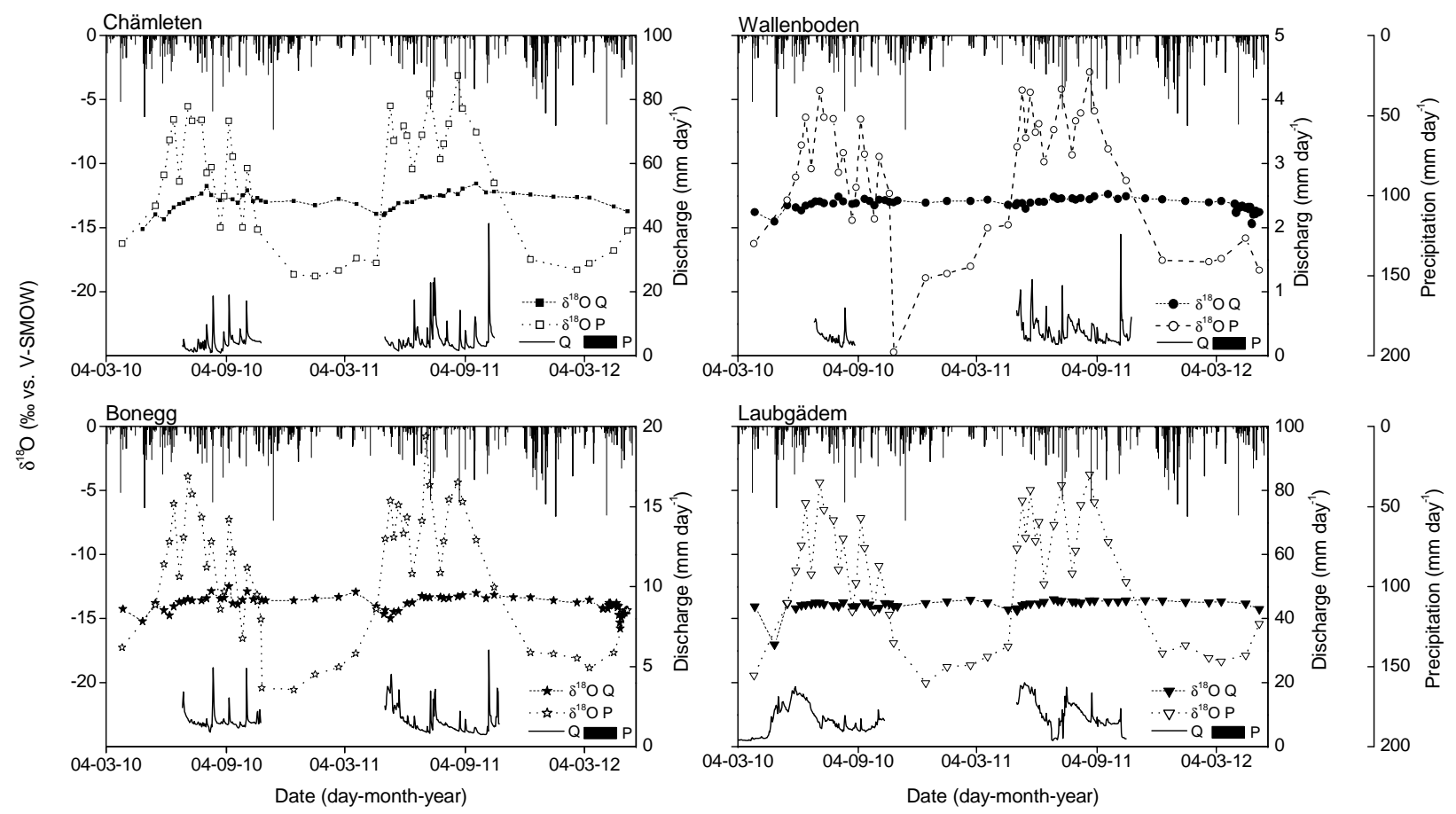

Fig. 4. Stable isotopes $\left(\delta^{18} \mathrm{O}\right.$ of $\left.\mathrm{H}_{2} \mathrm{O}\right)$ of precipitation $(P$, open symbols $)$ and stream water $(Q$, filled symbols $)$ in the four micro catchments, discharge data (bottom of each plot; note the different scales), and precipitation data from the MeteoSwiss station Andermatt at the top of each plot (MeteoSwiss, 2012; scale on the rightmost side applies to all four plots).

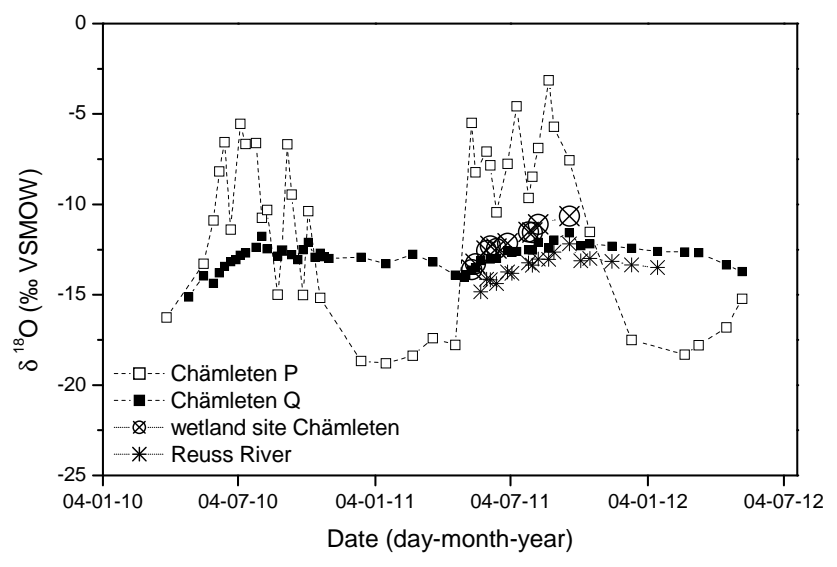

Fig. 5. Stable isotopes $\left(\delta^{18} \mathrm{O}\right.$ of $\left.\mathrm{H}_{2} \mathrm{O}\right)$ of subsurface/overland flow in a Chämleten wetland site and the Reuss River. Stable isotope signals of precipitation ( $P$, open symbols) and stream water base flow ( $Q$, filled symbols) of the Chämleten micro catchment are shown for comparison.

In contrast to the snowmelt period, all $\delta^{18} \mathrm{O}$ values of stream water were extremely stable during the winter period (Fig. 4). $\delta^{18} \mathrm{O}$ values of stream water reflect the approximate weighted mean $\delta^{18} \mathrm{O}$ of previous winter and summer precipitation. Hence, the isotope signal of snow is only reflected in the streams during snowmelt. During the winter 2010/2011 there was an increase in $\delta^{18} \mathrm{O}$ of base flow samples especially in the micro catchments Bonegg and Laubgädem. This was not the case in the next winter of 2011/2012. This could be explained by the higher precipitation amounts in summer 2010, which then discharged during the winter 2010/2011. In summer 2011 there were $160 \mathrm{~mm}$ less precipitation than in 2010 , which corresponds to a decrease of about $25 \%$ of summer precipitation.

In 2011 we also measured stable isotopes of the Reuss River (Fig. 5). Our sampling point was the outlet of a $132 \mathrm{~km}^{2}$ subcatchment of the Ursern Valley that drains north and south facing slopes (note that the whole Ursern catchment has an area of $191 \mathrm{~km}^{2}$ ). Because the sampling point integrates a much larger area than our micro catchments, we can qualitatively compare hydrological characteristics of different scales. The data series for the larger Reuss subcatchment only covers the summer period in 2011 and we consider this time span too short for quantitative modeling of MTT. But from the similar stream water stable isotope pattern of the micro catchments and the Reuss subcatchment, we can conclude that water storage and flow in the fractured bedrock also plays an important role at the larger catchment scale. Also, the comparable pattern of stream water stable isotopes suggests that MTT in the Reuss subcatchment is presumably equal to or even longer than in the micro catchments.

We also determined $\delta^{18} \mathrm{O}$ values of subsurface/overland flow which we collected in a wetland soil site in the Chämleten micro catchment during or shortly after 
precipitation events (Fig. 5). They are more positive than the respective stream water samples (taken at base flow conditions). This indicates the influence of quickly discharging precipitation, which has not traveled through deeper zones, in subsurface/overland flow and a smaller influence of preevent groundwater.

\subsection{Mean water transit time modeling}

\subsubsection{Mean water transit times}

We first will introduce some aspects of sensitivity and uncertainty of the used modeling approach and then give the results of MTT modeling.

The sensitivity analysis with different flow models revealed that model parameters could be identified unambiguously (data not shown). The piston flow and the linear model gave unrealistic stream water stable isotope values (compared to the measured ones) and high values of $\sigma$. The exponential model gave overall the best fits and also performed better than the exponential-piston-flow model and the dispersion model. With an apparent dispersion parameter $\left(P_{\mathrm{D}}=\right.$ reciprocal of the Péclet number) of 0.5 to 0.8 we also obtained good fits for the dispersion model, and the dispersion and the exponential distributions are quite similar with these chosen $P_{\mathrm{D}}$ values, but reproduction of the measured values was always better using the exponential model. Moreover, due to the hydrogeological situation we preferred the exponential model because a good mixing of all the waters within these steep aquifers is highly unlikely.

The uncertainty analysis with different model input parameter sets (Table 2) revealed that a minimum value of $\sigma$ for each parameter set could be identified (Fig. 6). For reasons of clarity we will only show the results of the uncertainty analysis for the exponential model. In general, the measured data were reproduced well for all catchments. MTTs range from 64 to 108 weeks (Figs. 6 and 7). The model efficiency $(E)$ is quite low (Fig. 7; except for Chämleten), which can be explained by the low variance of measured stream water stable isotope values. The measured values are often close to their mean. For the Chämleten and the Bonegg micro catchment, the minimum of the $\sigma$ value of all five sets cluster around a quite narrow range of MTTs of 64 to 85 weeks, respectively (Fig. 6). The discrepancy of the minimum $\sigma$ value between sets $\mathrm{A}+\mathrm{B}$ and $\mathrm{C}+\mathrm{D}+\mathrm{E}$ increases in the order Chämleten - Bonegg - Wallenboden - Laubgädem (Fig. 6). Nevertheless, even the very rough input sets A and B (raw $\delta^{18} \mathrm{O}$ values of precipitation and volume weighted $\delta^{18} \mathrm{O}$ values of precipitation, respectively) gave similar MTTs compared to the more complex parameter sets $\mathrm{C}$ to $\mathrm{E}$. Moreover, even the strong dampening of the stable isotope input signal $(-25$ to $-5 \%$ ) to the narrow range of -15 to $-12 \%$ in stream water was quite well reproduced by the rough parameter sets $\mathrm{A}$ and $\mathrm{B}$, except for the Laubgädem micro catchment (Fig. 7). From the uncertainty analysis with the five different model input parameter sets we roughly estimate the uncertainty of our modeling approach to be about 10 to 15 weeks. Calculated average MTT of the more complex parameters sets $\mathrm{C}$ to $\mathrm{E}$ are 70 to 102 weeks (Table 3). The parameter sets $\mathrm{C}$ to $\mathrm{E}$ gave similar output of stable isotope values compared among each other (Fig. 7). In general, the difference between these three parameter sets can be observed in the modeled data of autumn/winter of 2011. During that time period there is an overestimation of the measured stable isotope values of base flow in the Wallenboden, Bonegg and Laubgädem catchments, which is the lowest for parameter sets D and E. In fact, there are slightly more positive $\delta^{18} \mathrm{O}$ values in summer precipitation samples from 2011 compared to 2010, which is also reflected in the slightly more positive base flow $\delta^{18} \mathrm{O}$ values in all four micro catchments (Figs. 4 and 7). But this effect was more pronounced in the modeled than in the measured data. The overestimation by the modeled data in autumn/winter 2011 could be either due to heavy rains in July 2011 that produce a steplike increase in modeled autumn/winter values, or that the increase in the measured data is small because the subsurface reservoir is refilled after the relatively dry periods in spring and summer 2011. Afterwards this water discharges to the streams. Therefore Chämleten must have a smaller storage reservoir since its reaction to precipitation input is more pronounced. Comparison of parameter sets $\mathrm{C}$ to $\mathrm{E}$ suggest that the overestimation could also be due to the underestimation of the snowmelt component (more details also see Sect. 3.2.2). In general, snowmelt was represented well with a six-weeks snowmelt approach. Especially the fast decline of $\delta^{18} \mathrm{O}$ at the onset of snowmelt was reproduced quite well by weighting the $\delta^{18} \mathrm{O}$ values of snow with the accumulated snow depths. Nevertheless, very sharp stream water peaks during snowmelt in March and April could not be modeled adequately in all cases. We measured, for example, a $-15 \%$ $\delta^{18} \mathrm{O}$ signal in the streams in 2010 in the Chämleten, Wallenboden and Bonegg micro catchments. These samples do not represent base flow samples by definition. But in this nival runoff regime, snowmelt takes place during several weeks and snow constitutes a substantial part of the water cycle in our micro catchments, especially in runoff throughout the months of May to August. Therefore, we included them in the modeling procedure. The probably shorter snowmelt period in 2010 can especially be seen in the Laubgädem micro catchment where we have a very large decrease of $\delta^{18} \mathrm{O}$ to about $-17 \%$, which increases to $-14 \%$ after 14 days only. This phenomenon can also not be reproduced by the model. After the six weeks of snowmelt in the lower parts of the catchments, the residual accumulated snow of the upper parts presumably slowly refills the reservoirs.

The steeper increase of $\delta^{18} \mathrm{O}$ values of stream water in summer 2010 in Chämleten was not clearly reproduced by the model. It underestimates the variability of $\delta^{18} \mathrm{O}$, which is higher in spring/summer 2010 in Chämleten and Bonegg than in Wallenboden and especially Laubgädem. Thus, MTT 

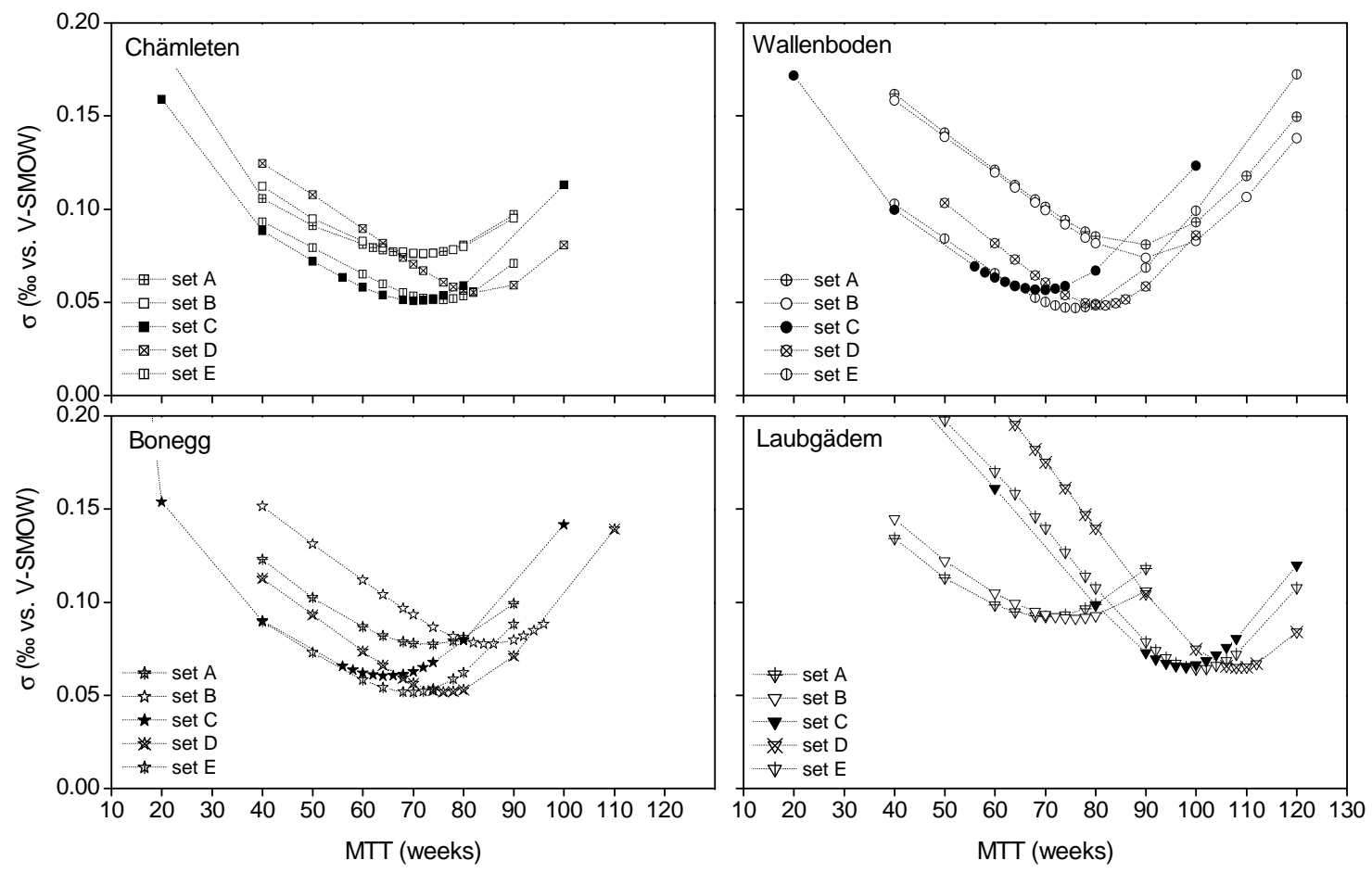

Fig. 6. Uncertainty analysis of MTT calculation for the micro catchments with different input parameter sets.

for Chämleten is probably lower compared to Wallenboden even if their range for parameters sets $\mathrm{C}, \mathrm{D}$ and $\mathrm{E}$ are similar for the best model fits (Fig. 6).

Generally, we think the applied exponential model could satisfactorily reproduce the measured stable isotope values of stream water and it also implicitly gives useful insights into the flow systems. However, it could not reproduce the relatively "short" snowmelt peaks (about 10 weeks) and the subsequent quick onset of more positive $\delta^{18} \mathrm{O}$ values with low variability throughout summer, autumn and winter. This is probably due to the time-invariant modeling approach and the fact that MTTs can be shorter and the dynamics in the aquifers can be higher during snowmelt periods.

\subsubsection{Fractionation of stable isotopes}

\section{Evaporation of soil water}

Evaporation of soil water can alter isotopic signals (Zimmermann et al., 1967). Viville et al. (2006) and Stumpp et al. (2009a) stated that the stable isotope input function for modeling MTTs can be improved by taking evapotranspiration into account. According to Barnes and Turner (1998), the influence of evaporation on stable isotopes signals is rather small in humid areas since other processes are prevailing (e.g. mixing and dispersion). Water uptake by plants does not alter isotope signatures of soil water (e.g. Dawson and Ehleringer, 1991; Ehleringer and Dawson, 1992; Zimmermann et al., 1967), but it could of course reduce amounts of precipitation water entering the deeper soil layers and the bedrock. In our micro catchments the volume weighted stable isotope signal of the precipitation input equals the mean stable isotope signal of the stream water output. Thus, the evapotranspiration from the north facing slopes most likely played a negligible role in shifting isotopic values. Moreover, the $\delta^{18} \mathrm{O}$ vs. $\delta^{2} \mathrm{H}$ plot does not indicate substantial evaporation since base flow, precipitation and snow samples plot near the global meteoric water line.

\section{Evaporation through interception}

Evaporation of water by interception can also change isotope signals in precipitation. Generally, throughfall enrichment is between 0.1 to $1.2 \%$ o.g. Ingraham, 1998; Saxena, 1986) but there are also studies in which throughfall was depleted in ${ }^{18} \mathrm{O}$ compared to bulk precipitation (Saxena, 1986). In our study we found some samples of throughfall in shrub sites to be enriched in ${ }^{18} \mathrm{O}$ by about $1.5 \%$ but more samples to be depleted in ${ }^{18} \mathrm{O}$ by about $0.6 \%$ compared to bulk precipitation samples in grassland sites. Since there was no general pattern, the differences were small and micro catchments include different surface cover types from vegetation (grass and shrubs) to bare rocks, we conclude that a possible influence of evaporation through interception should play a minor role for the modeling. 

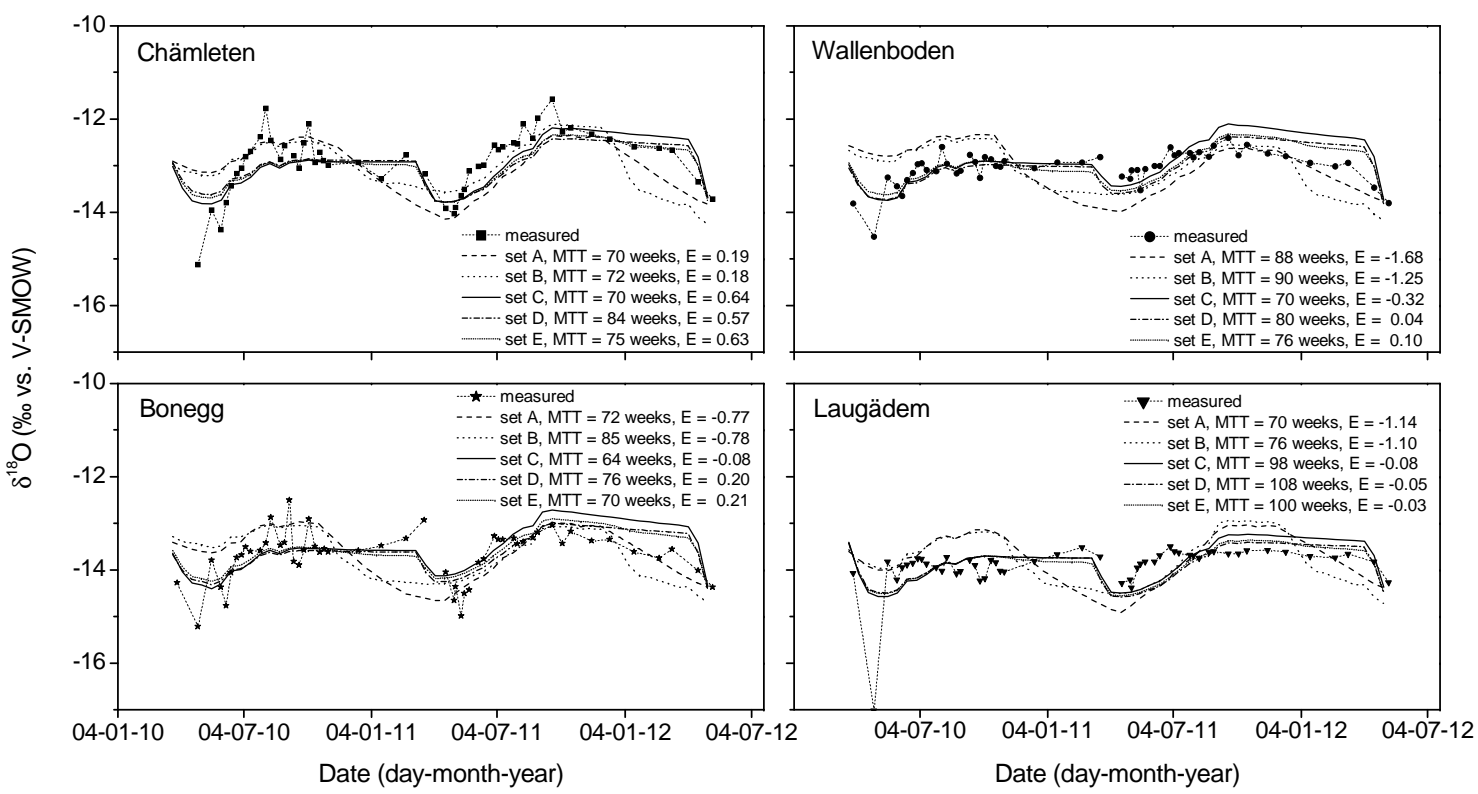

Fig. 7. Measured and modeled stable isotopes $\left(\delta^{18} \mathrm{O}\right.$ of $\left.\mathrm{H}_{2} \mathrm{O}\right)$ in stream water base flow in the four micro catchments. The best fit according to Fig. 6 for each input parameter set and the model efficiency $(E)$ according to Nash and Sutcliffe (1970) are shown.
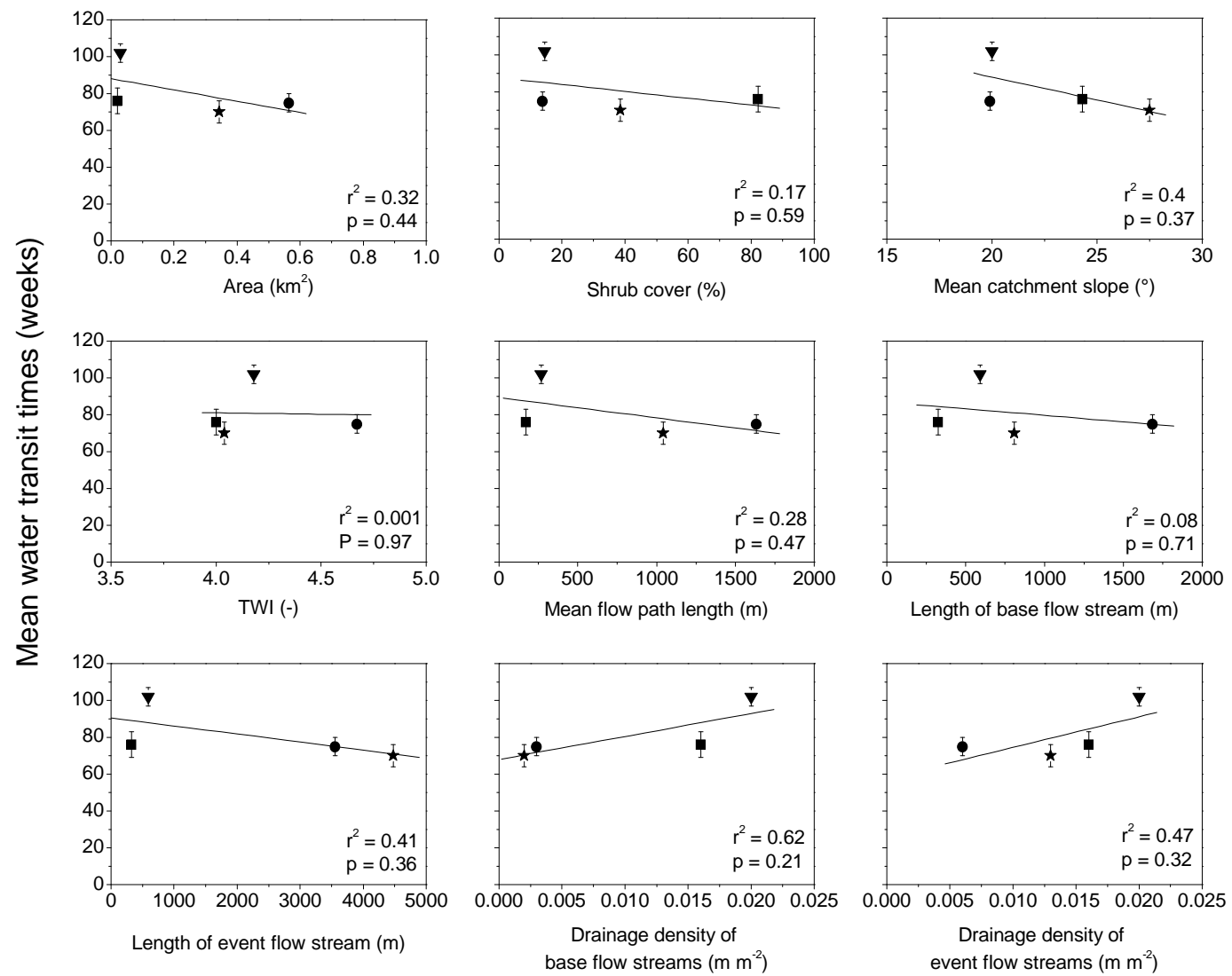

Fig. 8. Correlation of MTT with topographic indices and shrub cover. Average MTTs of parameter sets $\mathrm{C}$ to $\mathrm{E}$ are shown. $\boldsymbol{\square}=\mathrm{Chämleten}$, $\bullet$ = Wallenboden, $\star=$ Bonegg, $\boldsymbol{\nabla}=$ Laubgädem. Micro catchment area and shrub cover data from Fercher (2013) and van den Bergh et al. (2011), modified. 


\section{Fractionation of stable isotopes in snow}

Snowmelt water input into the system could also be a critical input component in MTT modeling. Evaporation of water from the snowpack during the winter and fractionation processes during melt can alter isotopic composition of the water infiltrating into the soil (Moser and Stichler, 1975). Again, we assume that substantial evaporation during the winter can be excluded because no shift from the global meteoric water line was measured for the bulk snow samples. These were taken a few days before the onset of snowmelt. Moreover, evaporation in March and April in our micro catchments is estimated to be very low (Baumgartner et al., 1983).

The bulk snow samples show slight enrichment of the heavier isotopes with time towards the end of the winter from about -17 to $-15 \%$. But the samples shortly after snowmelt that were taken on some shadowed locations where snow was still available only showed a small enrichment of the heavier isotope compared to the samples before the onset of snowmelt. Moreover, they plot around the local meteoric water line even after snowmelt in the lower parts of the micro catchments occurred (Fig. 3). These facts indicate that evaporation (under equilibrium) during melt occurred to a certain extent. But for model parameter set $\mathrm{C}$ (Table 2) we assumed that the isotope signal from our depth integrating bulk snow samples just before the onset of snowmelt could be regarded as our input signal in our modeling interval of two weeks. Water balance estimates suggest that the major fraction of the total accumulated snow recharges to the aquifer, and since we are not looking at short temporal variations during snowmelt we can assume that the mean stable isotope signal of our bulk snow samples represents the model input signal that recharges into the aquifer. Nevertheless, since the first meltwater can be depleted in the heavier isotope (e.g. Taylor et al., 2001), uncertainty is introduced to the model results by taking bulk snow samples as the model input. In order to estimate the influence of the fractionation processes during snowmelt on our modeled data, we also considered a modified parameter set D (Table 2) where we estimated the first meltwater to be depleted in the heavier isotope by about 2\%o (Taylor et al., 2001). The results are discussed in Sect. 3.2.1.

\subsubsection{Length of data record}

McGuire and McDonnell (2006) argued that the length of the data record for the input function should exceed the MTT by a factor of 4 to 5 . This would ensure that tracer mass recovery would be nearly $100 \%$. According to Hrachowitz et al. (2011), the required minimum length of the data record in their study was 3 times the MTT in order to maximize tracer mass recovery. Our record is about $2 \mathrm{yr}$ and MTTs are 1.2 to $2.1 \mathrm{yr}$. We therefore extended our input record backwards in time by correlating stable isotopes in precipitation with air temperature measured at the valley bottom. Although stable isotopes of precipitation are not solely dependent on air temperature (e.g. Ingraham, 1998), we obtained a good linear correlation between stable isotope values of precipitation and air temperature for the Ursern Valley $\left(\delta^{18} \mathrm{O}=0.73 \cdot T\right.$ $\left.\left({ }^{\circ} \mathrm{C}\right)-16.89, r^{2}=0.84, p<0.0001, n=145\right)$. Extending the stable isotope time series by this technique has been successfully used by other authors and has proved to be a valuable tool to extrapolate stable isotope data (Burns and McDonnell, 1998; Uhlenbrook et al., 2002; Hrachowitz et al., 2011). With this prolongated time series we tested the modeling procedure for the Laubgädem and the Chämleten micro catchments. We could not improve our model results of MTT calculation with the longer data record. Therefore we used our measured input record of about $2 \mathrm{yr}$ for the modeling, as described above.

\subsection{Influences on mean water transit time}

\subsubsection{Effect of vegetation cover and topography}

The two largest micro catchments Wallenboden and Bonegg with a shrub cover of $13.8 \%$ and $38.5 \%$, respectively, and the smallest micro catchment Chämleten with the highest shrub cover of $82.2 \%$ have a similar range of MTTs of 64 to 90 weeks (Figs. 6 and 7). Moreover, the micro catchments Laubgädem and Wallenboden with a similar fraction of shrub cover have MTTs of 102 and 75 weeks, respectively (average MTT of parameter sets $\mathrm{C}$ to E). The correlation between MTT and shrub cover is weak and statistically not significant $\left(r^{2}=0.17, p=0.59\right.$, Fig. 8) and we therefore conclude that shrub cover most likely does not influence base flow MTT in these steep alpine headwater catchments. We are aware that the evaluation of a data set of four points with spearman correlation is critical. However, we feel that visualization in giving $r^{2}$ and $p$ is helpful if interpretation is done with caution.

Infiltration/recharge and transpiration could also be out of phase, which would affect the influence of vegetation on the water balance and its isotopic characteristics (Brooks et al., 2010). The seasonality of precipitation and its stable isotope signals and the seasonality of transpiration could produce different water pools (i.e. soil water vs. groundwater) with different isotopic characteristics, analogous to the findings of Brooks et al. (2010) and Goldsmith et al. (2012). Brooks et al. (2010) found that evaporation changed stable isotope values of soil water. However, soil water pools, which were used by plants, did not substantially contribute to stream water in their study. The latter showed no evidence of evaporative enrichment. These processes might be present at our sites since there exists a strong seasonality of water input, which is manifest in the snow dynamics. However, we consider it to be of minor importance with regard to the overall hydrological balance of precipitation and stream water and their stable isotope characteristics. Alaoui et al. (2013) also estimate that effect of vegetation cover (i.e. evapotranspiration) 
on the hydrological balance plays a minor role at our sites, especially on the investigated north facing slopes.

Roa-Garcia and Weiler (2010) found the vegetation cover (i.e. the percentage of wetlands and forest) to increase the transit time of water. The authors argued that wetlands and forests have a higher water storage capacity. This is in contrast to our findings where the Chämleten micro catchment, which includes some wetland sites, revealed the highest dynamic of stream water stable isotope values and the shortest MTT. The wetland sites in Chämleten were nearly water saturated throughout the year. Thus, the function of these wetlands of buffering inflowing water and subsequently the transit time of water can be reduced.

Overall, we estimate the influence of the vegetation cover on the MTT of base flow to be negligible in our catchments. The increase of soil hydraulic conductivity, induced by invading shrubs (Alaoui et al., 2013), seems to be of minor importance since high stone content and texture of the soils can mask the effect of roots.

Since the influence of vegetation cover on MTT seems to be of minor importance, we were also interested in possible influence of other factors (e.g. topography) on MTT. In contrast to the findings of McGlynn et al. (2003), McGuire et al. (2005), Rodgers et al. (2005) and Soulsby and Tetzlaff (2008), MTT in our study is not related to any of the calculated topographic indices (Fig. 8). Slight trends can be seen, but since in our study the range of MTT is small (Figs. 7 and 8) and the range of most of the calculated topographic indices is relatively high, we conclude that at our sites, with catchments smaller than $1 \mathrm{~km}^{2}$, MTT does not depend on any of the calculated topographic indices. In contrast to McGuire et al. (2005) for example, we found no relation of MTT with mean catchment slope or the topographic wetness index (TWI). In accordance with several other studies (McGlynn et al., 2003; McGuire et al., 2005; Rodgers et al., 2005; Soulsby and Tetzlaff, 2008; Tetzlaff et al., 2009), MTT is not related to catchment size in our study. The larger (Wallenboden and Bonegg) and the smaller micro catchments (Chämleten and Laubgädem) have both relatively long and short MTTs. A qualitative comparison of the pattern of stream water stable isotopes of the Reuss River with the four micro catchments (Figs. 4 and 5) also suggests that there exists no relation between catchment size and MTT. However, the range of our catchment size is small compared to other studies (e.g. Tetzlaff et al., 2009) and we considered the time series of the larger Reuss subcatchment too short for quantitative modeling.

Tetzlaff et al. (2011) stated that a greater contribution of groundwater inputs weakens the influence of topographic controls. The importance of groundwater contribution, inferred from geochemical data and estimated hydrogeological parameters, will be discussed below.
Table 4. Means and standard deviations of geochemical parameters of stream base flow samples in $\mathrm{mg} \mathrm{L}^{-1}$.

\begin{tabular}{lllll}
\hline & Chämleten & Wallenboden & Bonegg & Laubgädem \\
\hline $\mathrm{Ca}(n=20)$ & $16.3(1.8)$ & $27.4(3.6)$ & $22.8(3.7)$ & $19.4(1.7)$ \\
$\mathrm{Mg}(n=20)$ & $0.9(0.1)$ & $1.6(0.1)$ & $2.2(0.3)$ & $0.8(0.1)$ \\
$\mathrm{Na}(n=20)$ & $0.9(0.1)$ & $1.0(0.1)$ & $1.3(0.1)$ & $0.7(0.1)$ \\
$\mathrm{K}(n=20)$ & $1.1(0.2)$ & $2.1(0.2)$ & $2.6(0.3)$ & $1.7(0.1)$ \\
$\mathrm{Si}(n=29)$ & $2.6(0.8)$ & $2.4(0.7)$ & $3.0(1.0)$ & $1.9(0.6)$ \\
$\mathrm{SO}_{4}^{2-}(n=27)$ & $10.8(1.5)$ & $14.7(1.4)$ & $19.7(3.2)$ & $7.3(0.7)$ \\
$\mathrm{pH}$ (summer) & $7.35(0.18)$ & $7.65(0.25)$ & $7.55(0.14)$ & $7.35(0.32)$ \\
$\mathrm{pH}$ (winter) & $7.30(0.26)$ & $7.54(0.26)$ & $7.56(0.25)$ & $7.68(0.13)$ \\
\hline
\end{tabular}

\subsubsection{Implications from geochemical and hydrogeological aspects}

Mean concentrations of total dissolved $\mathrm{Ca}, \mathrm{Mg}, \mathrm{Na}$ and $\mathrm{K}$ (Table 4) are higher than can be expected from similar geological and climatological settings with mainly granitic or gneiss materials (e.g. Drever and Zobrist, 1992; Ofterdinger, 2001; Tardy, 1971). Ofterdinger (2001) and Ofterdinger et al. (2004) studied stable isotopes and other geochemical parameters of groundwater in the western Gotthard massif (granitic Rotondo massif) only a few km south-west of our sites. They measured, for example, calcium concentrations of up to $9 \mathrm{mg} \mathrm{L}^{-1}$ for surface waters, springs and groundwaters. Mean sulfate concentrations at our sites range from 7.3 to $19.7 \mathrm{mg} \mathrm{L}^{-1}$ (Table 4), which is also slightly higher than we would expect from a mere magmatic or metamorphic geological setting ( 1 to $8 \mathrm{mg} \mathrm{L}^{-1}$ ) (e.g. Drever and Zobrist, 1992; Ofterdinger, 2001; Tardy, 1971). Sulfate rich minerals seem to be dissolved by the percolating water. Mean silicon concentrations (Table 4) are slightly lower than compared to other granitic or gneiss regions with comparable climate (e.g. Drever and Zobrist, 1992; Tardy, 1971). Silicon could be a product of weathering of quartz veins, which are very common in this zone of fractured rocks (Winterhalter, 1930). Overall, our data show that dissolution of magmatic or metamorphic minerals alone cannot account for the measured concentrations of solutes. The $\mathrm{pH}$ of stream water of more than 7 suggests dissolution of evaporative minerals, i.e. karst formation, in the deeper bedrock. Moreover, soil $\mathrm{pH}$ in our micro catchments is about 4 to 5 . Therefore, infiltrating precipitation must be strongly buffered in the deeper aquifer below the soils. Low $\mathrm{pH}$ of water leaching from the soil, in turn, could accelerate weathering of rocks.

Ofterdinger et al. (2004) concluded that water can percolate in the fractured granitic rocks of the Rotondo massif (only a few km south-west of our sites), which will lead to a strong dampening of the stable isotope input signal. Additionally, the phenomenon of strong isotope signal dampening is also known from karstic environments (e.g. Bakalowicz et al., 1974; Maloszewski et al., 1992, 2002; Perrin et al., 2003). This suggests that the rocks in our test sites are highly 
fractured and have a high porosity and storage capacity. Water percolating in these systems will have relatively longer transit times compared to an unfractured system with low storage capacity. Of course water storage capacity, water flow and consequently the MTT will then also depend on the form, the extent and the connectivity of fractures and fissures and not only on their frequency (e.g. Banks et al., 2009).

We estimated porosities of $7 \times 10^{-4}$ to $8 \times 10^{-2}$, which are in the same order of magnitude as values given by Frick (1994) and Himmelsbach et al. (1998) for a geological complex in the Aar massif containing fault zones. They measured porosities between $7.4 \times 10^{-3}$ and $1.3 \times 10^{-3}$, respectively. Porosity in the intact Rotondo granite with moderate fracturation are lower and range from $2.4 \times 10^{-5}$ to $2.9 \times 10^{-4}$ (Ofterdinger, 2001). Our estimates for hydraulic conductivities (Table 3) are at the upper end together with fault zone and sedimentary rocks (Ofterdinger, 2001). Ofterdinger (2001) gave hydraulic conductivities for different rock types in the Rotondo area, ranging from $5.3 \times 10^{-9}$ to $4.0 \times 10^{-7} \mathrm{~m} \mathrm{~s}^{-1}$. This strongly supports the conclusion of fractured rocks in the micro catchments in which water can percolate into the deeper bedrock. The lack of relation between mean mobile catchment storage and catchment surface area indicates that surface and subsurface catchment area are not equal and water can be delivered via subsurface flow paths from the upslope bedrock to the micro catchments. This in turn could mask possible influences of topographic indices on MTTs since these indices were calculated for the surface catchment areas.

Consequently, the strong attenuation of the stable isotope input signal can be explained by a combination of water flowing in the fractures and fissures of the rocks and in cavities that can be produced by dissolution of readily soluble minerals (gypsum, dolomite or calcite). Our findings support the conclusions of, e.g Gabrielli et al. (2012) and Asano and Uchida (2012), who underlined the importance of water flow in the subsurface and bedrock and its control on MTT.

\section{Conclusions}

We investigated the influence of differing percentage of shrub cover on MTTs in four mountainous micro catchments. Stream water stable isotope signals during base flow conditions over two years point to mixing of waters of different ages, resulting in MTTs of at least 1 yr. Our data suggest that neither shrub vegetation cover nor topography nor catchment size influence the MTT of base flow. The shrub encroachment does not seem to increase MTTs and other factors other than surficial catchment characteristics mainly controlled MTTs at our sites.

The snowmelt input into the micro catchments and its release during spring was identified as an important influence on mean stable isotope signals and for MTT modeling. Geochemical data from stream water suggest that water percolates through partially karstified deeper bedrock at all four investigated catchments. This in turn favors mixing of water and storage in the deeper bedrock, which leads to a strong attenuation of the $\delta^{18} \mathrm{O}$ signal of precipitation input in our alpine headwater catchments. Furthermore, our estimates of hydrogeological parameters indicate that subsurface storage and flow paths strongly control MTTs. The major part of the precipitation input enters the bedrock systems rather quickly, which leads to a sustained discharge of this bedrock groundwater to base flow in our micro catchments.

We therefore conclude that, in our mountainous headwater catchments with relatively shallow soil layers, the hydrogeological and geochemical patterns and snow dynamics influence storage, mixing and release of precipitation in a stronger way than vegetation cover does. The effect of vegetation on MTT can be masked at the catchment scale in such a setting.

Acknowledgements. We would like to thank Mark Rollog and Marianne Caroni for laboratory analyses and Claude Schneider for technical support. We also thank Thijs van den Bergh (Group of Botany, Section Plant Ecology, University of Basel) and Mathias Fercher (Institute of Geography, Section Hydrology, University of Bern) for providing data of catchment sizes and vegetation cover, Abdallah Alaoui, Susanne Lagger and Philipp Schmidt (Institute of Geography, Section Hydrology, University of Bern) for providing discharge data and estimates on evapotranspiration rates, and Katrin Meusburger (Environmental Geosciences, University of Basel) for calculating the TWI. Lothar Schroeder, Yannick Bucher, Robin Nager, Jonas Gessler and Gyula Csato helped during sampling campaigns. We also would like to thank the anonymous referees for their constructive comments and suggestions, which helped to improve our manuscript, and Christine Stumpp as the editor of this manuscript.

This work was part of the project "The ecological and socioeconomic consequences of land transformation in alpine regions: an interdisciplinary assessment and VALuation of current changes in the Ursern Valley, key region in the Swiss central Alps", funded by the Swiss National Science Foundation, grant no. CR30I3_124809.

Edited by: C. Stumpp

\section{References}

Alaoui, A., Willimann, E., Jasper, K., Felder, G., Herger, F., and Weingartner, R.: Modelling the effects of land use and climate changes on hydrology in the Ursern valley, Switzerland, Hydrol. Process., accepted, 2013.

Ambach, W., Dansgaard, W., Eisner, H., and Moller, J.: The altitude effect on isotopic composition of precipitation and glacier ice in the Alps, Tellus, 20, 595-600, 1968.

Ambuehl, E.: Petrographie und Geologie des zentralen Gotthardmassivs südlich Andermatt, PhD Thesis, A.G. Gebr. Leemann, Zürich, 1929. 
Amin, I. E. and Campana, M. E.: A general lumped parameter model for the interpretation of tracer data and transit time calculation in hydrologic systems, J. Hydrol., 179, 1-21, doi:10.1016/0022-1694(95)02880-3, 1996.

Angehrn, P.: Hydrogeologische Grundlagen, Urserental, Kanton Uri, Amt für Umweltschutz, Abteilung Gewässerschutz, 1996.

Asano, Y. and Uchida, T.: Flow path depth is the main controller of mean base flow transit times in a mountainous catchment, Water Resour. Res., 48, W03512, doi:10.1029/2011wr010906, 2012.

Bachmair, S., Weiler, M., and Nützmann, G.: Controls of land use and soil structure on water movement: Lessons for pollutant transfer through the unsaturated zone, J. Hydrol., 369, 241-252, doi:10.1016/j.jhydrol.2009.02.031, 2009.

Bakalowicz, M., Blavoux, B., and Mangin, A.: Use of natural isotopic tracers in studying functioning of a karstic system oxygen-18 contents of 3 systems in Pyrenes, France, J. Hydrol., 23, 141-158, doi:10.1016/0022-1694(74)90028-6, 1974.

Banks, E. W., Simmons, C. T., Love, A. J., Cranswick, R., Werner, A. D., Bestland, E. A., Wood, M., and Wilson, T.: Fractured bedrock and saprolite hydrogeologic controls on groundwater/surface-water interaction: a conceptual model (Australia), Hydrogeol. J., 17, 1969-1989, doi:10.1007/s10040009-0490-7, 2009.

Bariac, T., Millet, A., Ladouche, B., Mathieu, R., Grimaldi, C., Grimaldi, M., Hubert, P., Molicova, H., Bruckler, L., Bertuzzi, P., Boulegue, J., Brunet, Y., Tournebize, R., and Granier, A.: Stream hydrograph separation on two small Guianese catchments, in: Tracer Technologies for Hydrological Systems, edited by: Leibundgut, C., IAHS-AISH P., 229, 193-209, 1995.

Barnes, C. J. and Turner, J. V.: Isotopic exchange in soil water, in: Isotope Tracers in Catchment Hydrology, edited by: Kendall, C. and McDonnell, J. J., Elsevier Science, Amsterdam, 137-163, 1998.

Baumgartner, A., Reichel, E., and Weber, G.: Der Wasserhaushalt der Alpen: Niederschlag, Verdunstung, Abfluß u. Gletscherspende im Gesamtgebiet d. Alpen im Jahresdurchschnitt für d. Normalperiode 1931-1960; mit 68 Tab, Bd. 1, R. Oldenbourg Verlag, München, 1983.

Beven, K. and Germann, P.: Macropores and waterflow in soils, Water Resour. Res., 18, 1311-1325, doi:10.1029/WR018i005p01311, 1982.

Beven, K. J. and Kirkby, M. J.: A physically based, variable contributing area model of basin hydrology/Un modèle à base physique de zone d'appel variable de l'hydrologie du bassin versant, Hydrological Sciences Bulletin, 24, 43-69, doi:10.1080/02626667909491834, 1979.

Botter, G., Bertuzzo, E., and Rinaldo, A.: Catchment residence and travel time distributions: The master equation, Geophys. Res. Lett., 38, L11403, doi:10.1029/2011g1047666, 2011.

Brooks, J. R., Barnard, H. R., Coulombe, R., and McDonnell, J. J.: Ecohydrologic separation of water between trees and streams in a Mediterranean climate, Nat. Geosci., 3, 100-104, doi:10.1038/ngeo722, 2010.

Bucher, Y.: Isotopendynamik des Abflusses in alpinen Einzugsgebieten im Urserntal während der Ablationsperiode, Bachelor Thesis, Environmental Geosciences, University of Basel, Basel, Switzerland, in preparation, 2013.
Bundt, M., Jaggi, M., Blaser, P., Siegwolf, R., and Hagedorn, F.: Carbon and nitrogen dynamics in preferential flow paths and matrix of a forest soil, Soil Sci. Soc. Am. J., 65, 1529-1538, 2001.

Burns, D. A. and McDonnell, J. J.: Effects of a beaver pond on runoff processes: comparison of two headwater catchments, J. Hydrol., 205, 248-264, doi:10.1016/s0022-1694(98)00081-x, 1998.

Buxtorf, A.: Über die geologischen Verhältnisse des Furkapasses und des im Bau befindlichen Furkatunnels, Eclogae Geol. Helv., 12, 176-178, doi:10.5169/seals-157268, 1912.

Buytaert, W., De Bièvre, B., Wyseure, G., and Deckers, J.: The use of the linear reservoir concept to quantify the impact of changes in land use on the hydrology of catchments in the Andes, Hydrol. Earth Syst. Sci., 8, 108-114, doi:10.5194/hess-8-108-2004, 2004.

Clark, I. D. and Fritz, P.: Environmental Isotopes in Hydrogeology, CRC Press/Lewis Publishers, New York, 352 pp., 1997.

Craig, H.: Isotopic variations in meteoric waters, Science, 133, 1702-1703, doi:10.1126/science.133.3465.1702, 1961.

Dansgaard, W.: Stable isotopes in precipitation, Tellus, 16, 436468, 1964.

Darling, W. G. and Bath, A. H.: A stable isotope study of recharge processes in the english chalk J. Hydrol., 101, 31-46, doi:10.1016/0022-1694(88)90026-1, 1988.

Dawson, T. E. and Ehleringer, J. R.: Streamside trees that do not use stream water, Nature, 350, 335-337, doi:10.1038/350335a0, 1991.

Dewalle, D. R., Edwards, P. J., Swistock, B. R., Aravena, R., and Drimmie, R. J.: Seasonal isotope hydrology of three Appalachian forest catchments, Hydrol. Process., 11, 18951906, doi:10.1002/(sici)1099-1085(199712)11:15<1895::aidhyp538>3.3.co;2-r, 1997.

Drever, J. I. and Zobrist, J.: Chemical weathering of silicate rocks as a function of elevation in the southern Swiss Alps, Geochim. Cosmochim. Ac., 56, 3209-3216, doi:10.1016/00167037(92)90298-w, 1992.

Ehleringer, J. R. and Dawson, T. E.: Water-uptake by plants - perspectives from stable isotope composition, Plant Cell Environ., 15, 1073-1082, doi:10.1111/j.1365-3040.1992.tb01657.x, 1992.

Eriksson, E.: Compartment Models and Reservoir Theory, Annu. Rev. Ecol. Syst., 2, 67-84, doi:10.1146/annurev.es.02.110171.000435, 1971.

Fercher, M.: Einfluss von Landnutzungsänderungen auf die Hochwassersituation im Urserental: Eine Untersuchung mit dem Model ZEMOKOST, Masters Thesis, Section of Hydrology, Institute of Geography, University of Bern, Bern, Switzerland, 2013.

Frick, U.: The Grimsel radionuclide migration experiment - a contribution to raising confidence in the validity of solute transport models used in performance assessment, in: GEOVAL ' 94 Validation Through Model Testing, Proceedings of an NEA/SKI Symposium, OECD Nuclear Energy Agency, 245-272, 1994.

Friedman, I. and Smith, G. I.: Deuterium content of snow cores from sierra nevada area, Science, 169, 467-470, doi:10.1126/science.169.3944.467, 1970.

Gabrielli, C. P., McDonnell, J. J., and Jarvis, W. T.: The role of bedrock groundwater in rainfall-runoff response at hillslope and catchment scales, J. Hydrol., 450, 117-133, doi:10.1016/j.jhydrol.2012.05.023, 2012. 
Gat, J. R.: Oxygen and hydrogen isotopes in the hydrologic cycle, Annu. Rev. Earth Planet. Sc., 24, 225-262, doi:10.1146/annurev.earth.24.1.225, 1996.

Goldsmith, G. R., Munoz-Villers, L. E., Holwerda, F., McDonnell, J. J., Asbjornsen, H., and Dawson, T. E.: Stable isotopes reveal linkages among ecohydrological processes in a seasonally dry tropical montane cloud forest, Ecohydrology, 5, 779-790, doi:10.1002/eco.268, 2012.

Grabczak, J., Maloszewski, P., Rozanski, K., and Zuber, A.: Estimation of the tritium input function with the aid of stable isotopes, Catena, 11, 105-114, doi:10.1016/s0341-8162(84)800119, 1984.

Gurtz, J., Zappa, M., Jasper, K., Lang, H., Verbunt, M., Badoux, A., and Vitvar, T.: A comparative study in modelling runoff and its components in two mountainous catchments, Hydrol. Process., 17, 297-311, doi:10.1002/hyp.1125, 2003.

Heidbuechel, I., Troch, P. A., Lyon, S. W., and Weiler, M.: The master transit time distribution of variable flow systems, Water Resour. Res., 48, W06520, doi:10.1029/2011wr011293, 2012.

Herrmann, A. and Stichler, W.: Groundwater-runoff relationships, Catena, 7, 251-263, doi:10.1016/0341-8162(80)90011-9, 1980.

Himmelsbach, T., Hotzl, H., and Maloszewski, P.: Solute transport processes in a highly permeable fault zone of lindau fractured rock test site (Germany), Ground Water, 36, 792-800, doi:10.1111/j.1745-6584.1998.tb02197.x, 1998.

Hrachowitz, M., Soulsby, C., Tetzlaff, D., Malcolm, I. A., and Schoups, G.: Gamma distribution models for transit time estimation in catchments: Physical interpretation of parameters and implications for time-variant transit time assessment, Water Resour. Res., 46, W10536, doi:10.1029/2010wr009148, 2010.

Hrachowitz, M., Soulsby, C., Tetzlaff, D., and Malcolm, I. A.: Sensitivity of mean transit time estimates to model conditioning and data availabilityle, Hydrol. Process., 25, 980-990, doi:10.1002/hyp.7922, 2011.

Ingraham, N. L.: Isotopic variations in precipitation, in: Isotope Tracers in Catchment Hydrology, edited by: Kendall, C. and McDonnell, J. J., Elsevier Science, Amsterdam, 87-118, 1998.

Jinhua, C., Hongjiang, Z., Wei, W., Youyan, Z., Ran, W., and Wenxing, L.: Effects of land use on preferential flow paths distributions in southwestern China, 2010 Second IITA International Conference on Geoscience and Remote Sensing (IITA-GRS 2010), 13 16, doi:10.1109/iita-grs.2010.5603182, 2010.

Kägi, H. U.: Die traditionelle Kulturlandschaft im Urserental; Beitrag zur alpinen Kulturgeographie, $\mathrm{PhD}$ Thesis, University of Zürich, Zürich, Switzerland, 1973

Kirchner, J. W., Feng, X. H., and Neal, C.: Fractal stream chemistry and its implications for contaminant transport in catchments, Nature, 403, 524-527, doi:10.1038/35000537, 2000.

Küttel, M.: Der subalpine Schutzwald im Urserental - ein inelastisches Oekosystem, Botanica Helvetica, 100/2, 1990.

Labhart, T. P.: Aarmassiv und Gotthardmassiv, Volume 63, Borntraeger, Berlin, 1977.

Lagger, S.: Auswirkungen der Landnutzungsänderungen auf den Wasserhaushalt im Urserntal, Masters Thesis, Section of Hydrology, Institute of Geography, University of Bern, Bern, Switzerland, 2012.

Maloszewski, P. and Zuber, A.: Determining the turnover time of groundwater systems with the aid of environmental tracers. 1. models and their applicability, J. Hydrol., 57, 207-231, 1982.
Maloszewski, P. and Zuber, A.: Manual on lumped-parameter models used for the interpretation of environmental tracer data in groundwaters, in: Use of Isotopes for Analyses of Flow and Transport Dynamics in Groundwater Systems, edited by: Yurtsever, Y., Vienna, 1-50, 2002.

Maloszewski, P., Rauert, W., Trimborn, P., Herrmann, A., and Rau, R.: Isotope hydrological study of mean transit times in an alpine basin (Wimbachtal, Germany), J. Hydrol., 140, 343-360, doi:10.1016/0022-1694(92)90247-s, 1992.

Maloszewski, P., Stichler, W., Zuber, A., and Rank, D.: Identifying the flow systems in a karstic-fissured-porous aquifer, the Schneealpe, Austria, by modelling of environmental O-18 and H-3 isotopes, J. Hydrol., 256, 48-59, doi:10.1016/s00221694(01)00526-1, 2002.

McDonnell, J. J., McGuire, K., Aggarwal, P., Beven, K. J., Biondi, D., Destouni, G., Dunn, S., James, A., Kirchner, J., Kraft, P., Lyon, S., Maloszewski, P., Newman, B., Pfister, L., Rinaldo, A., Rodhe, A., Sayama, T., Seibert, J., Solomon, K., Soulsby, C., Stewart, M., Tetzlaff, D., Tobin, C., Troch, P., Weiler, M., Western, A., Wörman, A., and Wrede, S.: How old is streamwater? Open questions in catchment transit time conceptualization, modelling and analysis, Hydrol. Process., 24, 1745-1754, doi:10.1002/hyp.7796, 2010.

McGlynn, B., McDonnell, J., Stewart, M., and Seibert, J.: On the relationships between catchment scale and streamwater mean residence time, Hydrol. Process., 17, 175-181, doi:10.1002/hyp.5085, 2003.

McGuire, K. J. and McDonnell, J. J.: A review and evaluation of catchment transit time modeling, J. Hydrol., 330, 543-563, doi:10.1016/j.jhydrol.2006.04.020, 2006.

McGuire, K. J., McDonnell, J. J., Weiler, M., Kendall, C., McGlynn, B. L., Welker, J. M., and Seibert, J.: The role of topography on catchment-scale water residence time, Water Resour. Res., 41, W05002, doi:10.1029/2004wr003657, 2005.

McGuire, K. J., Weiler, M., and McDonnell, J. J.: Integrating tracer experiments with modeling to assess runoff processes and water transit times, Adv. Water Resour., 30, 824-837, doi:10.1016/j.advwatres.2006.07.004, 2007.

MeteoSwiss, Federal Office of Meteorology and Climatology: IDAweb The data portal of MeteoSwiss for research and teaching, available at: www.meteoschweiz.admin.ch/web/en/services/ data_portal/idaweb.html (last access: 1 June 2012), 2012.

Meusburger, K. and Alewell, C.: Impacts of anthropogenic and environmental factors on the occurrence of shallow landslides in an alpine catchment (Urseren Valley, Switzerland), Nat. Hazards Earth Syst. Sci., 8, 509-520, doi:10.5194/nhess-8-509-2008, 2008.

Monteith, S. S., Buttle, J. M., Hazlett, P. W., Beall, F. D., Semkin, R. G., and Jeffries, D. S.: Paired-basin comparison of hydrologic response in harvested and undisturbed hardwood forests during snowmelt in central Ontario: II. Streamflow sources and groundwater residence times, Hydrol. Process., 20, 1117-1136, doi:10.1002/hyp.6073, 2006.

Moran, T. A., Marshall, S. J., Evans, E. C., and Sinclair, K. E.: Altitudinal Gradients of Stable Isotopes in Lee-Slope Precipitation in the Canadian Rocky Mountains, Arct. Antarct. Alpine Res., 39, 455-467, doi:10.1657/1523-0430(06-022)[moran]2.0.co;2, 2007. 
Moser, H. and Stichler, W.: Deuterium and oxygen-18 contents as an index of the properties of snow blankets, in: Snow Mechanics: Proceedings of the Grindelwald Symposium April 1974, Publication number 114, International Association of Hydrological Sciences, Grindelwald, Switzerland, 122-135, 1975.

Nash, J. E. and Sutcliffe, J. V.: River flow forecasting through conceptual models part I - A discussion of principles, J. Hydrol., 10, 282-290, doi:10.1016/0022-1694(70)90255-6, 1970.

Ofterdinger, U. S.: Ground Water Flow Systems in the Rotondo Granite, Central Alps (Switzerland), PhD Thesis, University of Zürich, Switzerland, 2001.

Ofterdinger, U. S., Balderer, W., Loew, S., and Renard, P.: Environmental isotopes as indicators for ground water recharge to fractured granite, Ground Water, 42, 868-879, 2004.

Perrin, J., Jeannin, P.-Y., and Zwahlen, F.: Epikarst storage in a karst aquifer: a conceptual model based on isotopic data, Milandre test site, Switzerland, J. Hydrol., 279, 106-124, doi:10.1016/s00221694(03)00171-9, 2003.

Roa-Garcia, M. C.: Wetlands and water dynamics in small headwater catchments of the Andes, PhD Thesis, Institute for Resources, Environment and Sustainability, University of British Columbia, Vancouver, Canada, 153 pp., 2009.

Roa-García, M. C. and Weiler, M.: Integrated response and transit time distributions of watersheds by combining hydrograph separation and long-term transit time modeling, Hydrol. Earth Syst. Sci., 14, 1537-1549, doi:10.5194/hess-14-1537-2010, 2010.

Rodgers, P., Soulsby, C., and Waldron, S.: Stable isotope tracers as diagnostic tools in upscaling flow path understanding and residence time estimates in a mountainous mesoscale catchment, Hydrol. Process., 19, 2291-2307, doi:10.1002/hyp.5677, 2005.

Rodhe, A., Nyberg, L., and Bishop, K.: Transit times for water in a small till catchment from a step shift in the oxygen 18 content of the water input, Water Resour. Res., 32, 3497-3511, doi:10.1029/95wr01806, 1996.

Saxena, R. K.: Estimation of canopy reservoir capacity and O-18 fractionation in throughfall in a pine, Nordic Hydrol., 17, 251260, 1986.

Schaub, M., Seth, B., and Alewell, C.: Determination of delta O-18 in soils: measuring conditions and a potential application, Rapid Commun. Mass Sp., 23, 313-318, doi:10.1002/rcm.3871, 2009.

Schmidt, P.: Auswirkungen der Landnutzungsänderung auf die Hydrologie im Urserental, Masters Thesis, Section of Hydrology, Institute of Geography, University of Bern, Bern, Switzerland, 2012.

Siegenthaler, U. and Oeschger, H.: Correlation of O-18 in precipitation with temperature and altitude, Nature, 285, 314-317, doi:10.1038/285314a0, 1980.

Soulsby, C. and Tetzlaff, D.: Towards simple approaches for mean residence time estimation in ungauged basins using tracers and soil distributions, J. Hydrol., 363, 60-74, doi:10.1016/j.jhydrol.2008.10.001, 2008.

Soulsby, C., Tetzlaff, D., and Hrachowitz, M.: Are transit times useful process-based tools for flow prediction and classification in ungauged basins in montane regions?, Hydrol. Process., 24, 1685-1696, doi:10.1002/hyp.7578, 2010.

Stumm, W. and Morgan, J. J.: Aquatic chemistry: chemical equilibria and rates in natural waters, Wiley, New York, 1996.

Stumpp, C., Stichler, W., and Maloszewski, P.: Application of the environmental isotope $\delta 180$ to study water flow in unsaturated soils planted with different crops: Case study of a weighable lysimeter from the research field in Neuherberg, Germany, J. Hydrol., 368, 68-78, doi:10.1016/j.jhydrol.2009.01.027, 2009a.

Stumpp, C., Maloszewski, P., Stichler, W., and Fank, J.: Environmental isotope $(\delta 180)$ and hydrological data to assess water flow in unsaturated soils planted with different crops: Case study lysimeter station "Wagna" (Austria), J. Hydrol., 369, 198-208, doi:10.1016/j.jhydrol.2009.02.047, 2009b.

Tardy, Y.: Characterization of principal weathering types by geochemistry of waters from some european and african crystalline massifs, Chem. Geol., 7, 253-271, 1971.

Tasser, E., Tappeiner, U., and Cernusca, A.: Ecological effects of land use changes in the European Alps, in: Global Change and Mountain Regions - A State of Knowledge Overview, edited by: Huber, U. M., Bugmann, H. K. M., and Reasoner, M. A., Springer, Dordrecht, The Netherlands, 413-425, 2005.

Taylor, S., Feng, X. H., Kirchner, J. W., Osterhuber, R., Klaue, B., and Renshaw, C. E.: Isotopic evolution of a seasonal snowpack and its melt, Water Resour. Res., 37, 759-769, doi:10.1029/2000wr900341, 2001.

Tetzlaff, D., Seibert, J., McGuire, K. J., Laudon, H., Burns, D. A., Dunn, S. M., and Soulsby, C.: How does landscape structure influence catchment transit time across different geomorphic provinces?, Hydrol. Process., 23, 945-953, doi:10.1002/hyp.7240, 2009.

Tetzlaff, D., Soulsby, C., Hrachowitz, M., and Speed, M.: Relative influence of upland and lowland headwaters on the isotope hydrology and transit times of larger catchments, J. Hydrol., 400, 438-447, doi:10.1016/j.jhydrol.2011.01.053, 2011.

Turner, J. V. and Barnes, C. J.: Modeling of isotopes and hydrogeochemical responses in catchment hydrology, in: Isotope Tracers in Catchment Hydrology, edited by: Kendall, C. and McDonnell, J. J., Elsevier Science, Amsterdam, 723-760, 1998.

Uhlenbrook, S., Frey, M., Leibundgut, C., and Maloszewski, P.: Hydrograph separations in a mesoscale mountainous basin at event and seasonal timescales, Water Resour. Res., 38, 31.1-31.14, doi:10.1029/2001wr000938, 2002.

van den Bergh, T., Hiltbrunner, E., and Körner, C.: A landcover map and land cover statistics for the Urserntal, Central Alps, Switzerland, Institute of Botany, Section Plant Ecology, University of Basel, Technical report, unpublished, 10 pp., 2011.

Viville, D., Ladouche, B., and Bariac, T.: Isotope hydrological study of mean transit time in the granitic Strengbach catchment (Vosges massif, France): application of the FlowPC model with modified input function, Hydrol. Process., 20, 1737-1751, doi:10.1002/hyp.5950, 2006.

Wenjie, L., Wenyao, L., Hongjian, L., Wenping, D., and Hongmei, L.: Runoff generation in small catchments under a native rain forest and a rubber plantation in Xishuangbanna, southwestern China, Water Environ. J., 25, 138-147, doi:10.1111/j.17476593.2009.00211.x, 2011.

Wettstein, S.: Grünerlengebüsche in den Schweizer Alpen: Ein Simulationsmodell aufgrund abiotischer Faktoren und Untersuchungen über morphologische und strukturelle Variabilität, Masters Thesis, University of Bern, Switzerland, 1999.

Winterhalter, R. U.: Zur Petrographie und Geologie des östlichen Gotthardmassivs, PhD Thesis, A.G. Gebr. Leemann, Zürich, 1930. 
Wittenberg, H.: Baseflow recession and recharge as nonlinear storage processes, Hydrol. Process., 13, 715-726, doi:10.1002/(sici)1099-1085(19990415)13:5<715::aidhyp775>3.0.co;2-n, 1999.

Zimmermann, U., Ehhalt, D., and Munnich, K. O.: Soil-water movement and evapotranspiration: Changes in the isotopic composition of the water, in: Isotopes in Hydrology, edited by: IAEA, International Atomic Energy Agency, Vienna, 567-584, 1967.
Zuber, A.: Review of existing mathematical models for interpretation of tracer data in hydrology, Report 1270/AP of the Institute of Nuclear Physics, Cracow, in: Mathematical models for the interpretation of tracer data in groundwater hydrology, edited by: IAEA, 69-116, 1986. 